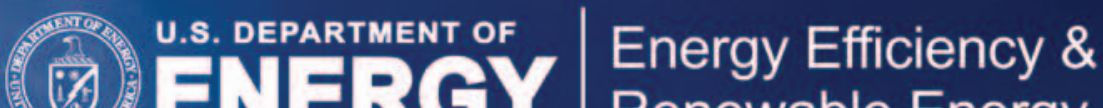

ENERGY Renenvabe Energy

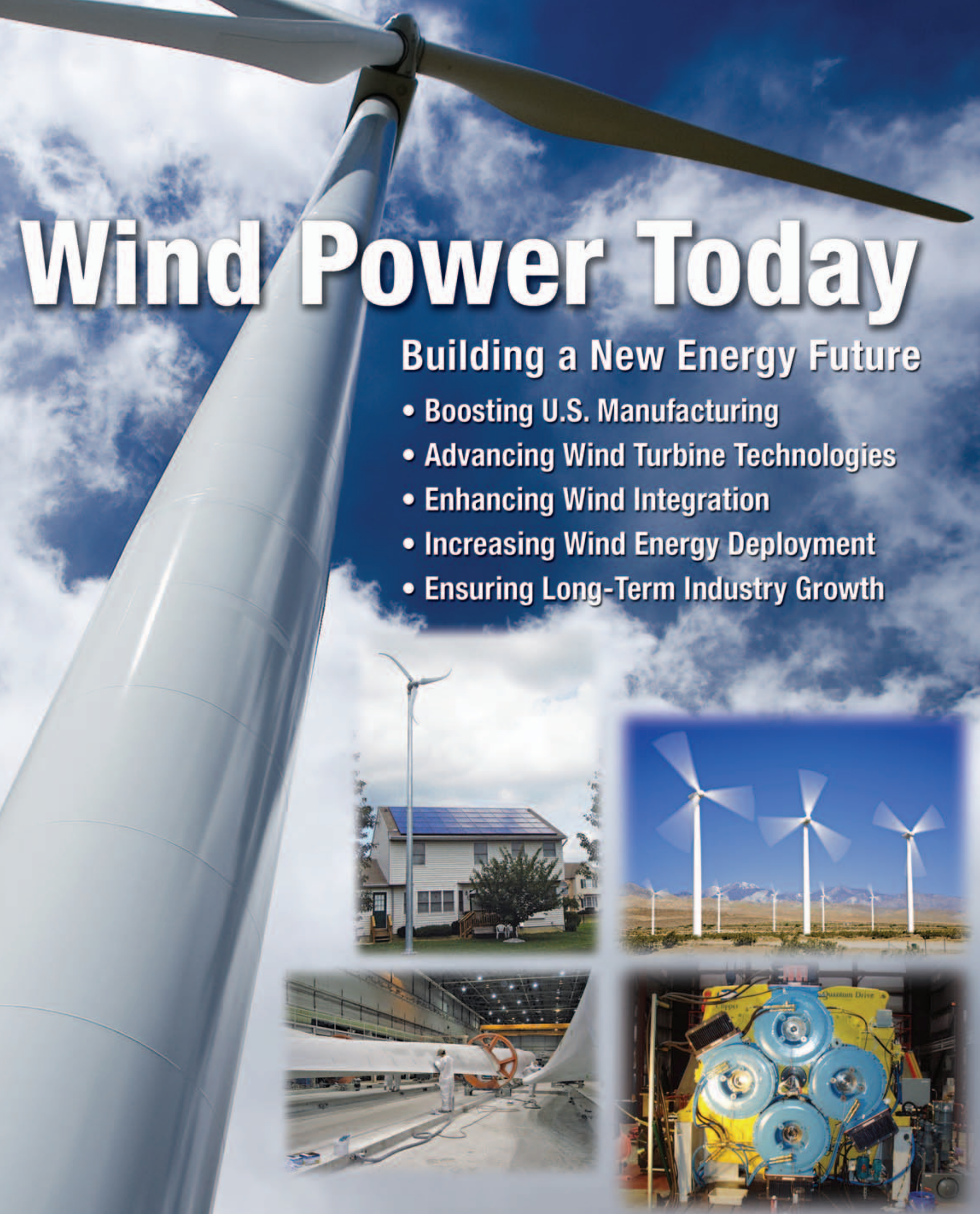

Whid and Bydropower lectinologles Progrtam • 2009 


\section{Contents}

BUILDING A NEW ENERGY FUTURE................................. 1

BOOSTING U.S. MANUFACTURING ................................... 5

ADVANCING LARGE WIND TURBINE TECHNOLOGY............ 7

GROWING THE MARKET FOR DISTRIBUTED WIND.......... 12

ENHANCING WIND INTEGRATION.................................. 14

INCREASING WIND ENERGY DEPLOYMENT ...................... 17

ENSURING LONG-TERM INDUSTRY GROWTH . 


\title{
BUILDING A NEW ENERGY FUTURE
}

\author{
We will harness the sun and the winds and the \\ soil to fuel our cars and run our factories....
}

— President Barack Obama, Inaugural Address, January 20, 2009

n 2008, wind energy enjoyed another record-breaking year of industry growth. By installing 8,358 megawatts (MW) of new generation during the year, the U.S. wind energy industry took the lead in global installed wind energy capacity with a total of $25,170 \mathrm{MW}$. According to initial estimates, the new wind projects completed in 2008 account for about $40 \%$ of all new U.S. powerproducing capacity added last year. The wind energy industry's rapid expansion in 2008 demonstrates the potential for wind energy to play a major role in supplying our nation with clean, inexhaustible, domestically produced energy while bolstering our nation's economy.

To explore the possibilities of increasing wind's role in our national energy mix, government and industry representatives formed a collaborative to evaluate a scenario in which wind energy supplies $20 \%$ of U.S. electricity by 2030 . In July 2008 , the U.S. Department of Energy (DOE) published the results of that evaluation in a report entitled 20\% Wind Energy by 2030: Increasing Wind Energy's Contribution to U.S. Electricity Supply. According to the report, the United States has more than 8,000 gigawatts (GW ) of available land-based wind resources that could be captured economically.

In the early release of its Annual Energy Outlook 2009, the U.S. Energy Information Administration (EIA) estimates that U.S. electricity consumption will grow from 3,903 billion kilowatt-hours ( $\mathrm{kWh}$ ) in 2007 to 4,902 billion kWh in 2030, increasing at an average annual rate of $1 \%$. To meet $20 \%$ of that demand, U.S. wind power capacity would have to reach more than $300 \mathrm{GW}(300,000 \mathrm{MW})$. This growth represents an increase of more than $275 \mathrm{GW}$ within 21 years. Although achieving $20 \%$ wind energy will have significant economic, environmental, and energy security benefits, to make it happen the industry must overcome significant challenges.

\section{Stimulating Economic Growth}

Achieving $20 \%$ wind energy by 2030 would have widespread economic benefits. The American Wind Energy Association (AWEA) reported that the wind industry employed about 85,000 workers and channeled approximately $\$ 17$ billion into the U.S. economy in 2008. Approximately 55 facilities for manufacturing wind-related equipment were announced or opened in 2008. Under the $20 \%$ wind energy scenario, the industry could support 500,000 jobs by 2030 , 180,000 of which would be directly related to the industry through construction, operations, and manufacturing.

In the decade preceding 2030, the $20 \%$ scenario would support 100,000 jobs in associated industries such as accountants, lawyers, steelworkers, and electrical manufacturing, and it will generate much needed income for rural communities. Farmers and landowners would gain more than $\$ 600$ million in annual land-lease payments and regional governments would gain more than $\$ 1.5$ billion annually in tax revenues by 2030 . Rural counties could use these taxes to fund new schools, roads, and other vital infrastructure, creating even more jobs for local communities.
Wind Energy Program Mission: The mission of DOE's Wind and Hydropower Technologies Program is to increase the development and deployment of reliable, affordable, and environmentally responsible wind and water power technologies in order to realize the benefits of domestic renewable energy production.

\section{Protecting the Environment}

Achieving $20 \%$ wind by 2030 would also provide significant environmental benefits in the form of avoided greenhouse gas emissions and water savings. For example, a 1.5-MW wind turbine can power 500 homes and displace 2,700 metric tons of carbon dioxide $\left(\mathrm{CO}_{2}\right)$ per year (the equivalent of planting 4 square kilometers of forest every year). According to AWEA, by the end of 2008, wind energy produced enough electricity to power approximately 7 million households and avoid nearly 44 million metric tons of emissions - the equivalent of taking more than 7 million cars off the road. Generating $20 \%$ of U.S. electricity from wind could avoid

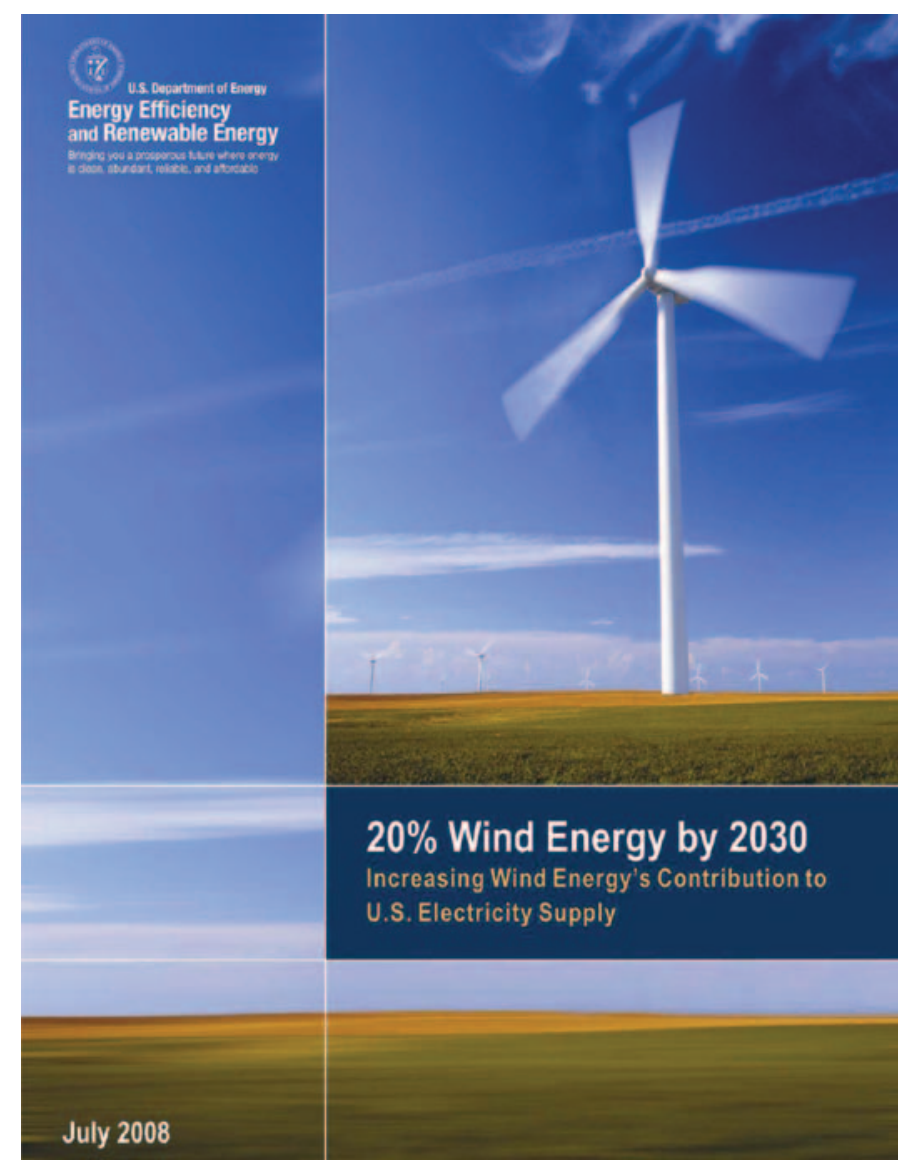

www1.eere.energy.gov/windandhydro/wind_2030.htm 


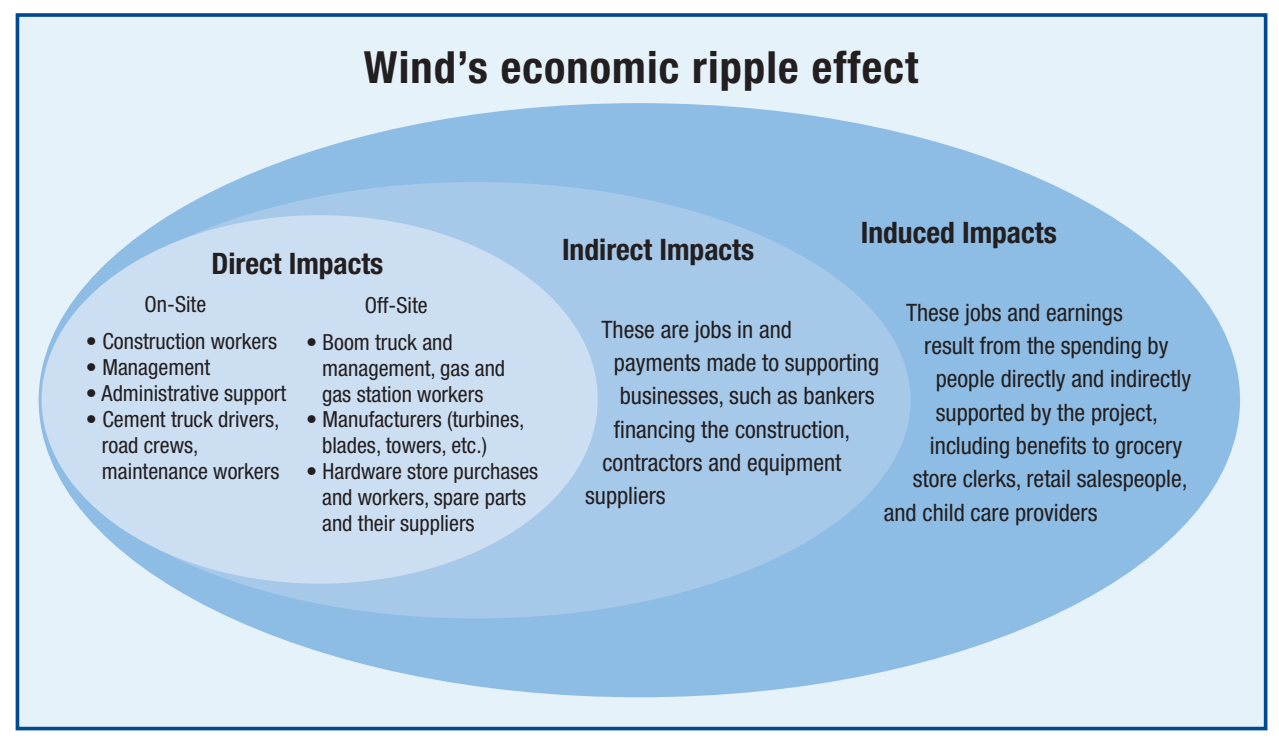

In addition to the need for expanding and improving the nation's transmission system, the natural variability of the wind resource can present challenges to grid system operators and planners with regard to managing regulation, load following, scheduling, line voltage, and reserves. Although the current level of wind penetration in the United States and around the world has provided substantial experience for successful grid operations with wind power, many grid operators are still concerned about the impacts that increasing the percentage of wind in their energy portfolios will have on system reliability. To increase utility understanding of integration and transmission issues associated with increased wind power generation, Wind Program

approximately 825 million metric tons of $\mathrm{CO}_{2}$ in the electric sector in 2030.

In addition to emissions reductions, the increased use of wind energy will reduce water consumption. Electricity generation accounts for $50 \%$ of all water withdrawals in our nation. The $20 \%$ wind scenario is projected to result in an $8 \%$ reduction (or 4 trillion gallons) in cumulative water use by the electric sector from 2007 through 2030. In 2030, annual water consumption in the electric sector will be reduced by $17 \%$.

\section{Meeting the Challenges}

The $20 \%$ report concluded that, although achieving $20 \%$ wind energy is technically feasible, it requires enhanced transmission infrastructure, increased U.S. manufacturing capacity, streamlined siting and permitting regimes, and improved reliability and operability of wind systems. To address these challenges, the DOE Wind Program collaborates with federal, state, industry, and stakeholder organizations to lead wind-energy technology research, development, and application efforts.

\section{Enhancing Wind Integration}

One of the challenges to meeting $20 \%$ of the nation's electricity demand with wind energy is moving the electricity from the often remote areas where it is produced to the nation's urban load centers. More transmission capacity and more sophisticated interconnections across the grid are needed to relieve congestion on the existing system, improve system reliability, increase access to energy at lower costs, and access new and remote generation resources. The Wind Program is working closely with the DOE Office of Electricity Delivery and Energy Reliability to effectively coordinate the DOE's contributions to the transmission planning efforts. This joint program effort will focus on linking remote regions with low-cost wind power to urban load centers, allowing thousands of homes and businesses access to abundant renewable energy. researchers at the DOE national laboratories are working with industry partners on mitigating interconnection impacts, electric power market rules, operating strategies, and system planning needed for wind energy to compete without disadvantage to serve the nation's energy needs.

\section{Increasing the Manufacturing Capacity and Growing a Skilled Workforce}

Achieving $20 \%$ wind energy would also support an expansion of the domestic manufacturing sector and related employment. To keep pace with this rapid growth, manufacturers need to develop robust and cost-effective manufacturing processes that incorporate automated systems to reduce labor intensity and increase

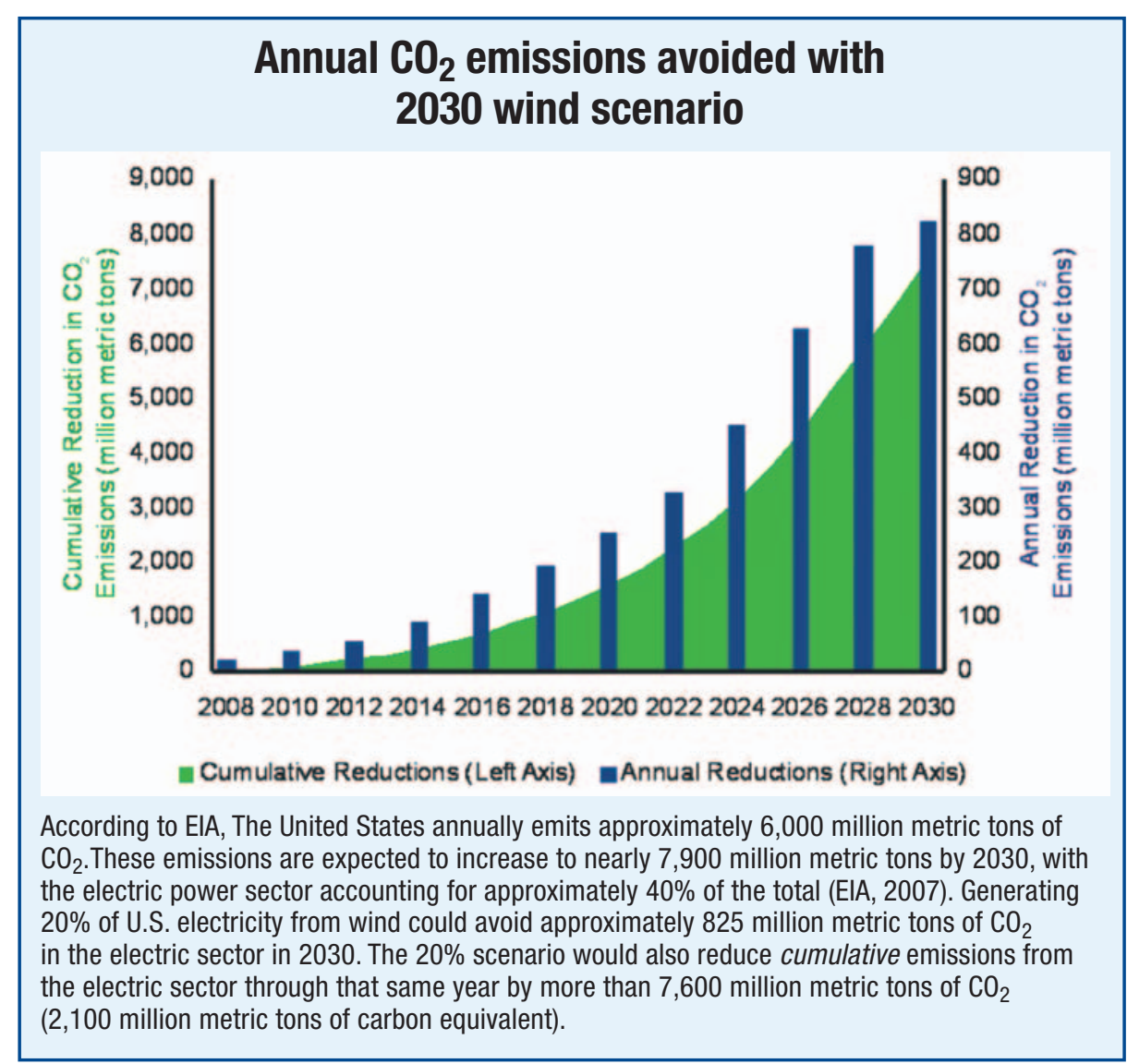




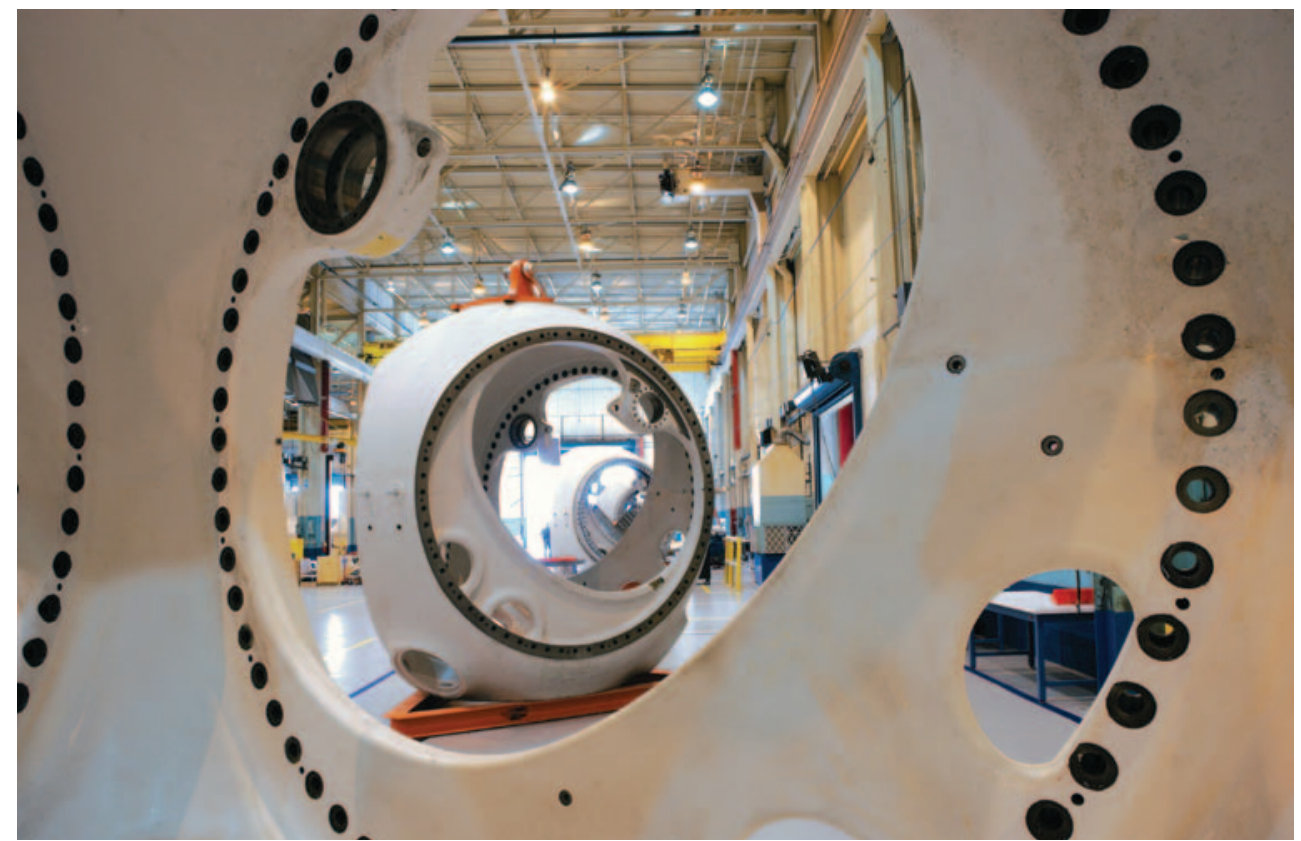

Clipper Windpower's wind turbine manufacturing facility in Cedar Rapids, lowa.

production. To fill the jobs created by this expansion, training programs are needed to provide a skilled workforce.

To facilitate this growth, the Wind Program is working with universities and industry members to incorporate advanced materials into wind turbine blades and investigate manufacturing process automation and fabrication techniques to reduce productto-product variability and premature failure while increasing the domestic manufacturing base. To grow the skilled workforce, the program works with universities and K-12 schools to develop vibrant wind energy educational programs in locations across the country.

\section{Advancing Wind Energy Technology}

DOE's Wind Program has worked with industry for more than 25 years to advance both large and small wind energy technologies and lower the cost of energy. For large wind technologies, these industry partnerships have succeeded in increasing capacity factors and dramatically reducing costs. Capacity factors have increased from about 22\% for wind turbines installed before 1998 to about 34\% for turbines installed between 2004 and 2006. Costs have been reduced from $\$ 0.80$ (current dollars) per kilowatt-hour $(\mathrm{kWh})$ in 1980 to between $\$ 0.05$ and $\$ 0.08 / \mathrm{kWh}$ today, so that in some areas of the nation, wind power has become the least expensive source of new utility-scale electricity generation.

In order to increase industry growth, however, the technology must continue to evolve, building on earlier successes to further improve reliability, increase capacity factors, and reduce costs. To this end, in 2008, DOE announced a Memorandum of Understanding (MOU) designed to advance wind power technologies and increase deployment. Under this MOU (http://www.energy.gov/media/DOE_ Turbine_Manufactures_MOU_5-31-08.pdf), DOE is cooperating with six leading wind turbine manufacturers: GE Energy, Siemens Power Generation, Vestas Wind Systems, Clipper Turbine Works, Suzlon Energy, and Gamesa Corporation. The two-year collaboration is designed to increase turbine performance and reliability.

\section{D0E's R\&D Capabilities}

To meet the many complex challenges facing the wind industry today, DOE draws on the capabilities and technical expertise found in nine of its national laboratories. The laboratories include: Argonne National Laboratory, Argonne, Illinois; Idaho National Laboratory, Idaho Falls, Idaho; Los Alamos National Laboratory, Los Alamos, New Mexico; Lawrence Berkeley National Laboratory, Berkeley, California; Lawrence Livermore National Laboratory, Livermore, California; National Renewable Energy Laboratory, Golden, Colorado; Oak Ridge National Laboratory, Oak Ridge, Tennessee; Pacific Northwest National Laboratory, Richland, Washington; and Sandia National Laboratories, Albuquerque, New Mexico.

As the lead wind energy research facility, the National Renewable Energy Laboratory (NREL) conducts research across the broad spectrum of engineering disciplines that are applicable to wind energy, including: atmospheric fluid mechanics and aerodynamics; dynamics, structures, and fatigue; power systems and electronics; wind turbine engineering applications; and systems integration. As the only facility in the United States accredited through the American Association of Laboratory Accreditation (A2LA) to perform several critical tests, NREL's National WInd Technology Center (NWTC) provides the high quality testing required by wind turbine certification agencies, financial institutions, and other organizations throughout the world. Tests accredited by A2LA to International Electrotechnical Commission (IEC) Standards include wind turbine noise, power performance, power quality, and several structural safety, function, and duration tests.

The Idaho National Laboratory (INL) has more than 10 years of experience in wind-radar interaction R\&D. INL staff work with wind

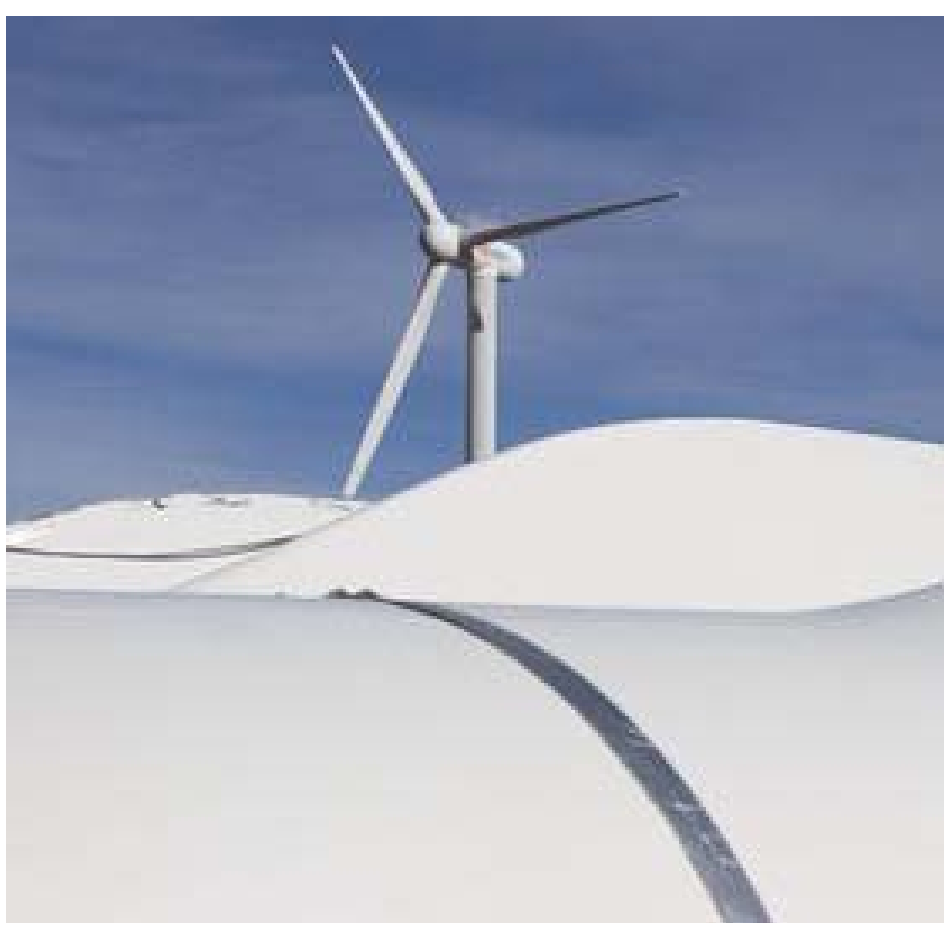

NREL's National Wind Technology Center provides high-quality testing for wind turbine systems and components. 
developers and radar site managers to mitigate wind-radar system interactions that may ultimately affect the development of wind plants. INL's windradar interaction $R \& D$ efforts include conducting site-specific assessments to develop guidelines; improving radar software; improving hardware; filtering algorithms, gap filling, and fused radar systems; improving small plane detection; providing better modeling techniques; and developing computer modeling systems to predict performance before construction.

Sandia National Laboratories (SNL) specializes in all aspects of wind turbine blade design and system reliability. Activities at SNL focus on reducing the cost of wind generated electricity and improving the reliability of systems operating nationwide. Research disciplines include: materials, airfoils, stress analysis, fatigue analysis, structural analysis, and manufacturing processes. By partnering with universities and industry, SNL has advanced the state of knowledge in the areas of materials, structurally efficient airfoil designs, active-flow aerodynamic control, and sensors.

Lawrence Berkeley National Laboratory (LBL) works with DOE, state and federal policymakers, electric suppliers, renewable energy firms, and others to evaluate state and federal renewable energy policies and provide expert assistance in policy design; analyze the markets for and economics of various renewable energy sources; and examine the benefits and costs of increased market penetration of renewable energy technologies with a focus on wind and solar power. LBL also spearheads the program's annual production of the Annual Report on U.S. Wind Power Installation, Cost, and Performance Trends.

The Argonne, Los Alamos, Lawrence Livermore, Oak Ridge, and Pacific Northwest National Laboratories all provide support for the program's systems integration research.

- Argonne National Laboratory (ANL) is developing improved methodologies for wind forecasting and working to increase the deployment of advanced wind forecasting techniques that will optimize overall grid reliability and system operations.

- Los Alamos National Laboratory (LANL) is conducting power flow analysis of the western interconnect of scenarios associated with $20 \%$ electricity from wind by 2030 and of scenarios to reach state renewable electricity standards.

- Lawrence Livermore National Laboratory (LLNL) is working to improve wind forecasting methods through the analysis and validation of SODAR and tall-tower data. Researchers at LLNL also work with utilities to effectively integrate improved wind forecasting information into control room operations.
Sandia National Laboratories developed an advanced data acquisition system (ATLAS II) on a GE Wind 1.5-MW wind turbine. The turbine is part of a cooperative activity involving SNL, GE Wind, and NREL.
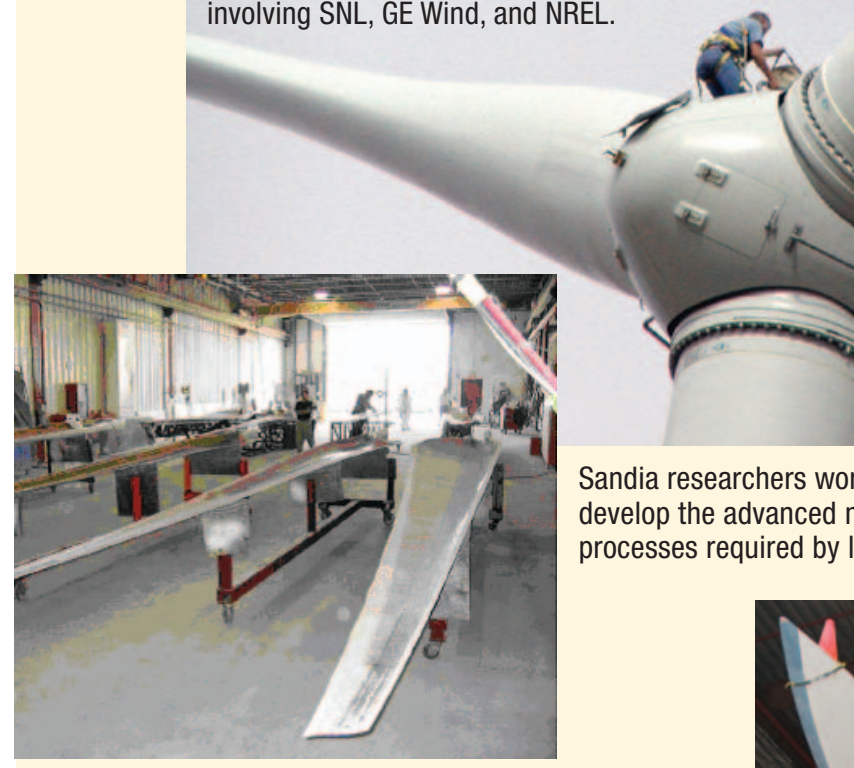


\section{BOOSTING U.S. MANUFACTURING}

More than $90 \%$ of these jobs will be in the private sector, jobs...
constructing wind turbines and solar panels.

—President Barack Obama, remarks to Congress and the American people, February 24, 2009

$\mathbf{T}$ he wind industry's recent rapid growth has accelerated job creation, particularly in manufacturing. In that sector, the share of domestically manufactured wind turbine components has grown from about $30 \%$ in 2005 to approximately $50 \%$ in 2008 . To ensure that this growth continues, the DOE Wind Program works with U.S. manufacturers to develop advanced fabrication techniques and automation processes that will enable them to increase their component production capabilities.

The focus of the fabrication and materials research is to reduce the rate of weight growth as the blades increase in size. Using advanced materials such as carbon and carbon/glass hybrids will reduce the

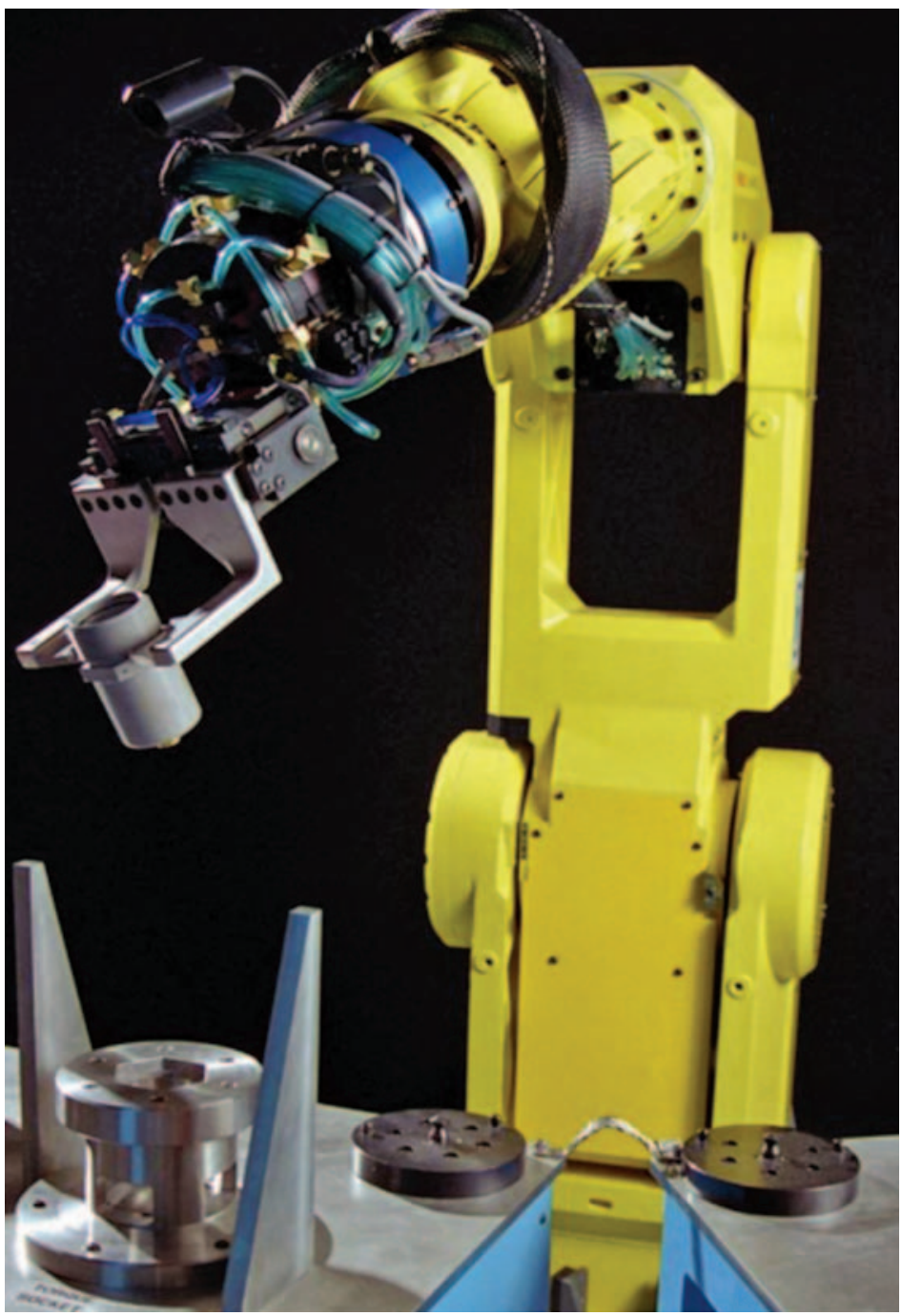

weight of the blade while increasing its strength and flexibility. By using advanced materials and optimized blade sensors to enhance reliability and load control, researchers hope to extend the life of blades as well as other turbine components to reduce repair and replacement costs.

The Wind Program is also exploring methods of improving resin transfer molding (RTM) and vacuum-assisted RTM manufacturing processes for utility-grade blades that incorporate automated processes to help manufacturers ensure consistent product quality and reduce labor.

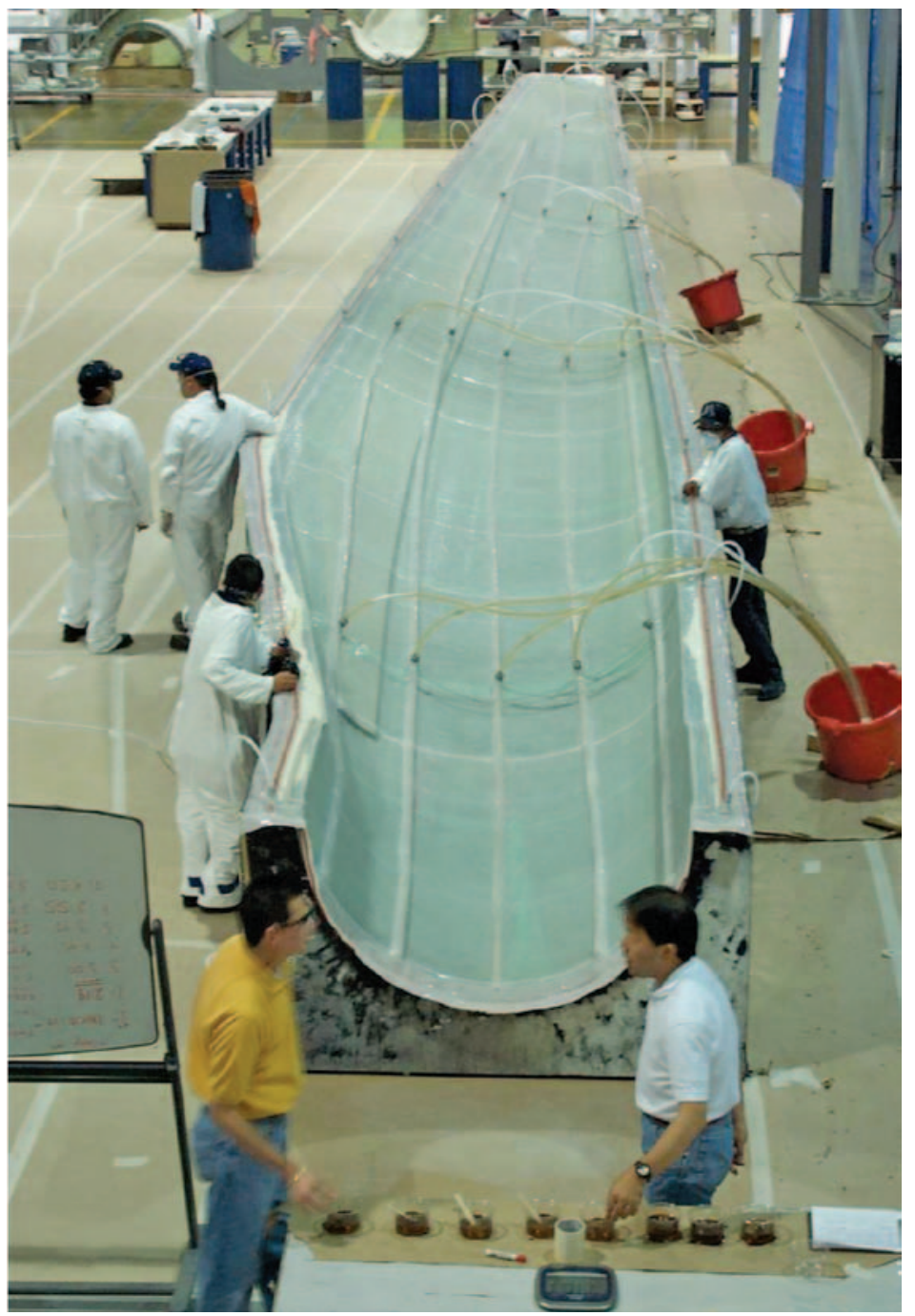

SNL works with industry partners to develop advanced fabrication techniques and automation processes. 


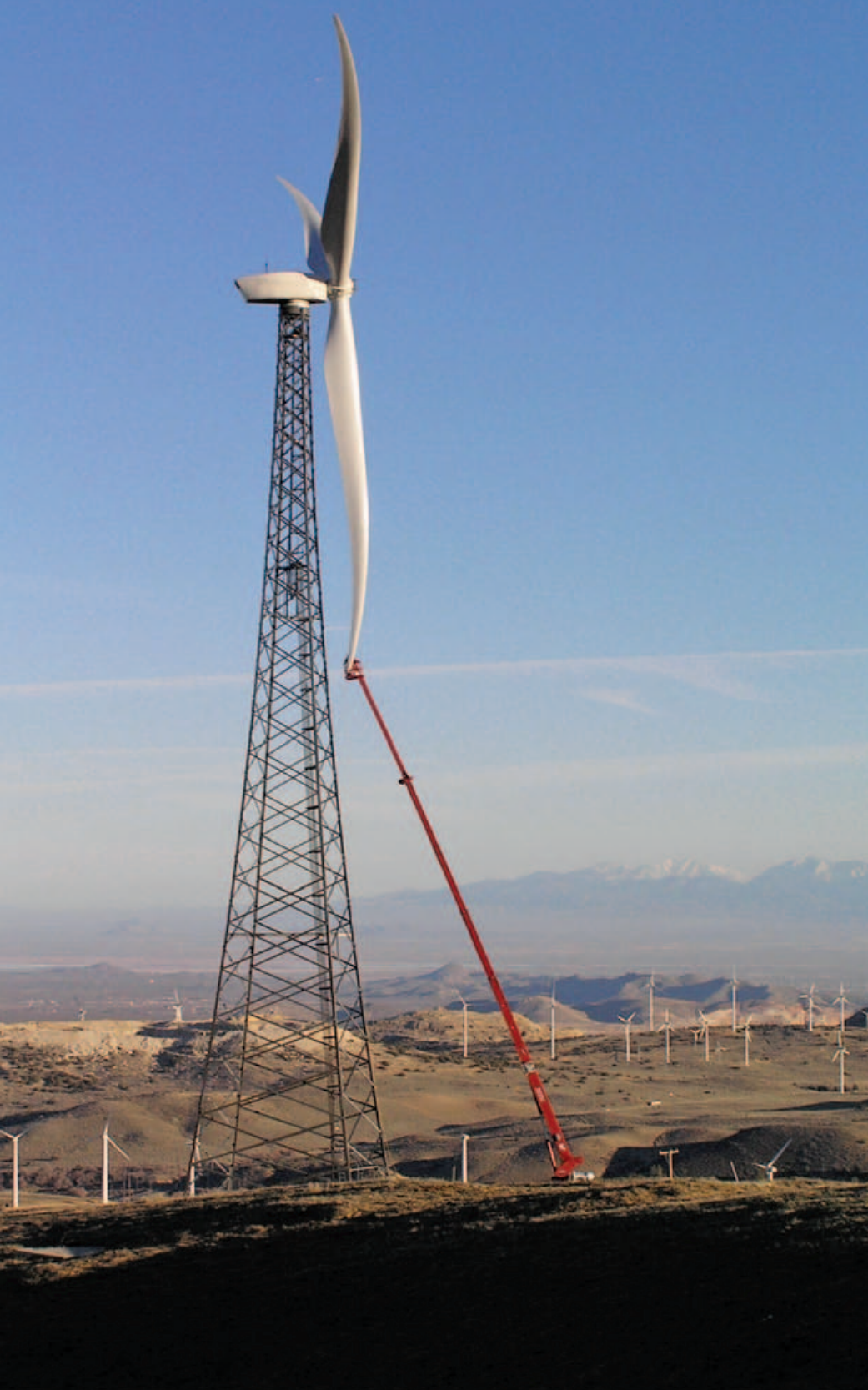

The DOE Wind Program worked with Knight \& Carver to develop an innovative wind turbine blade that the company expects to increase energy capture by $5 \%$ to $9 \%$. The most distinctive feature of the Sweep Twist Adaptive Rotor (STAR) blade is its gently curved tip.

During the past few years, the Wind Program has worked with blade manufacturer Knight \& Carver to develop an innovative wind turbine blade design that is the first of its kind to be produced at a utility-grade size, and which promises to be more efficient than conventional designs. Made of fiberglass and epoxy resin, the Sweep Twist Adaptive Rotor (STAR) blade is $27 \mathrm{~m}$ long-almost $3 \mathrm{~m}$ longer than the blade it will replace. Instead of the traditional linear shape, the blade curves toward the trailing edge, which allows it to respond to turbulent gusts in a manner that reduces fatigue loads on the blade. The STAR blade was specially designed for maximum energy capture at low wind speed sites. Knight \& Carver expects that STAR will increase energy capture by $5 \%$ to $9 \%$, significantly reducing the cost of energy (COE) of wind turbines at low-wind-speed sites. STAR can be deployed at sites with annual average wind speeds of 5.8 meters per second $(\mathrm{m} / \mathrm{s})$, measured at $10-\mathrm{m}$ height. Such sites are abundant in the United States. The ability to site turbines in these areas would increase twentyfold the available land area on which wind energy can be economically developed.

The Wind Program's blade manufacturing research also includes work to develop:

- More efficient blade structures, such as thick airfoils with designs that fully integrate structure and aerodynamics, along with slenderized blade geometries

- Adaptive structures, such as passive bend-twist coupling and active-aero devices

- Design details to minimize stress concentrations in ply drop regions (ply drop-off is a technique widely used to achieve gradual thickness change in composite laminate, and it can be used to form boundary tapering of a composite patch bonded to a parent structure)

- Less expensive, embedded blade root attachment devices

\section{Creating Advanced Materials}

Today's utility-scale wind turbine blades are fabricated with conventional composite materials such as fiberglass, polyester and vinyl ester resins, and core (balsa or foam). They have a rotor diameter span between $57 \mathrm{~m}$ and $90 \mathrm{~m}$ and have a power generation capacity of between $1 \mathrm{MW}$ and $3 \mathrm{MW}$. The newest turbine design concepts will take wind power generation far beyond the 1-MW to 3-MW range and will require much larger turbine blades with more efficient architectures, load alleviation concepts, and a higher content of carbon fiber and epoxy resins.

Wind Program researchers are developing several new blade material options for wind turbine manufacturers, including carbon, carbon-hybrid, S-glass, and other new material forms. They are creating design details that minimize stress concentrations in ply drop-off regions and are developing less expensive, embedded blade attachment devices.

One of the program's latest studies conducted by researchers at SNL presents an overview of composite laminates for wind turbine blade construction and summarizes test results for three prototype blades that incorporate a variety of structural and material innovations. The study examines recent SNL-sponsored material fatigue testing performed at Montana State University and provides highlights of the SNL/Global Energy Concepts Blade System Design Study-Phase II research that tested a variety of carbon and carbonhybrid materials. The blades tested under this study survived 20-year equivalent fatigue test loads thus demonstrating the value of incorporating carbon into wind turbine blades. Although cost and market stability remain as challenges for large implementation of carbon in commercial designs, the methodologies developed by these projects will enable blades to be lighter, stronger, and smarter. For more information on the studies conducted at SNL visit www. sandia.gov/wind/topical.htm. 


\section{ADVANCING LARGE WIND TURBINE TECHNOLOGY}

We've also made the largest investment in basic research funding in American history, an investment that will spur not only new discoveries in energy, but breakthroughs ... in science and technology.

-President Barack Obama, remarks to Congress and the American people, February 24, 2009 size and capacity, from 100-kW machines with a 17-m rotor diameter to multimegawatt machines with rotor diameters larger than $100 \mathrm{~m}$, while greatly reducing the cost of wind energy. Although these improvements in performance, reliability and cost have all contributed to the success enjoyed by the wind industry today, to achieve $20 \%$ wind energy, the technology must continue to evolve. Continued incremental improvements can further reduce system cost and increase performance and reliability. These improvements can only be achieved through a systems development and integration approach. No single component improvement in cost or efficiency can achieve the cost reduction or improved capacity factor that system-level advances can achieve.

Capacity factors can be increased by using larger rotors on taller towers, which requires innovative design approaches and advanced materials, controls, and power systems. Costs can be reduced and

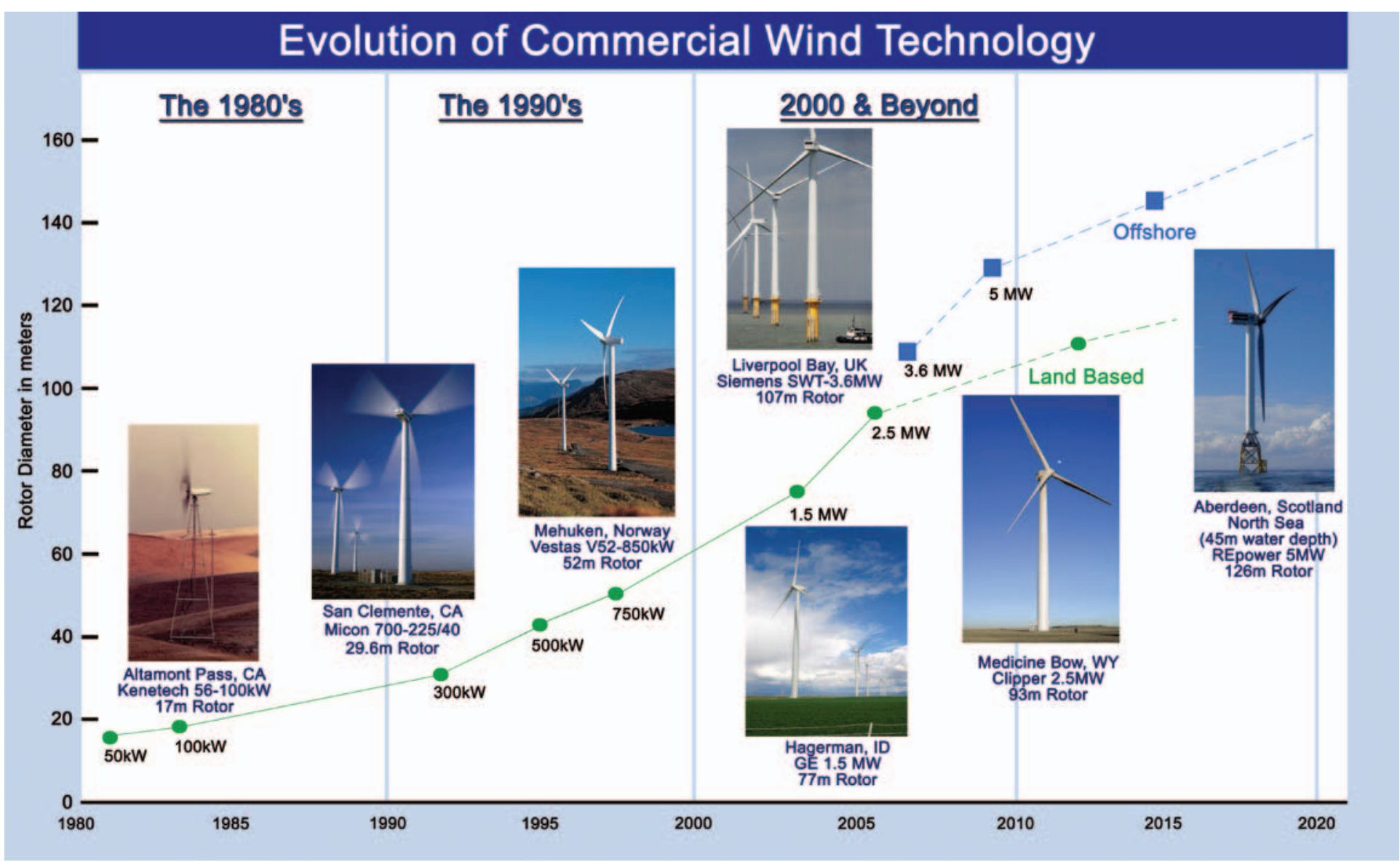

Since 1980, wind turbines have grown in size and capacity, from 100-kW machines with a 17-m rotor diameter to multimegawatt machines with rotor diameters larger than $100 \mathrm{~m}$. 
reliability increased through the advanced designs and materials that reduce weight and hence reduce the loads on the machines.

\section{Enhancing Turbine Reliability}

Program researchers continue to work on creating more reliable components, improving turbine capacity factors and reducing installation, operation, and maintenance costs. To help identify reliability issues, the Wind Program created a national reliability database to gather and store wind farm operations data. Analysts examine these data and report baseline reliability statistics. Program researchers use these analyses to launch technology improvement projects where critical reliability issues are discovered, and invite manufacturers and wind-plant owners and operators to participate. For the past two years, SNL has sponsored public Wind Turbine Reliability Workshops to facilitate partnerships and information exchange across the industry. These workshops identify and examine some of the most pressing reliability, operation, and maintenance issues experienced by operators, developers, turbine suppliers, and component vendors.

\section{Gearboxes}

Gearbox reliability is a major issue for the wind energy industry. Gearbox replacement and lubrication account for $38 \%$ of the parts cost for the entire turbine system. Recurrent gearbox failures have plagued the industry since the technology's inception and they continue to prevent the turbines from achieving their intended 20- to 25-year lifespan.
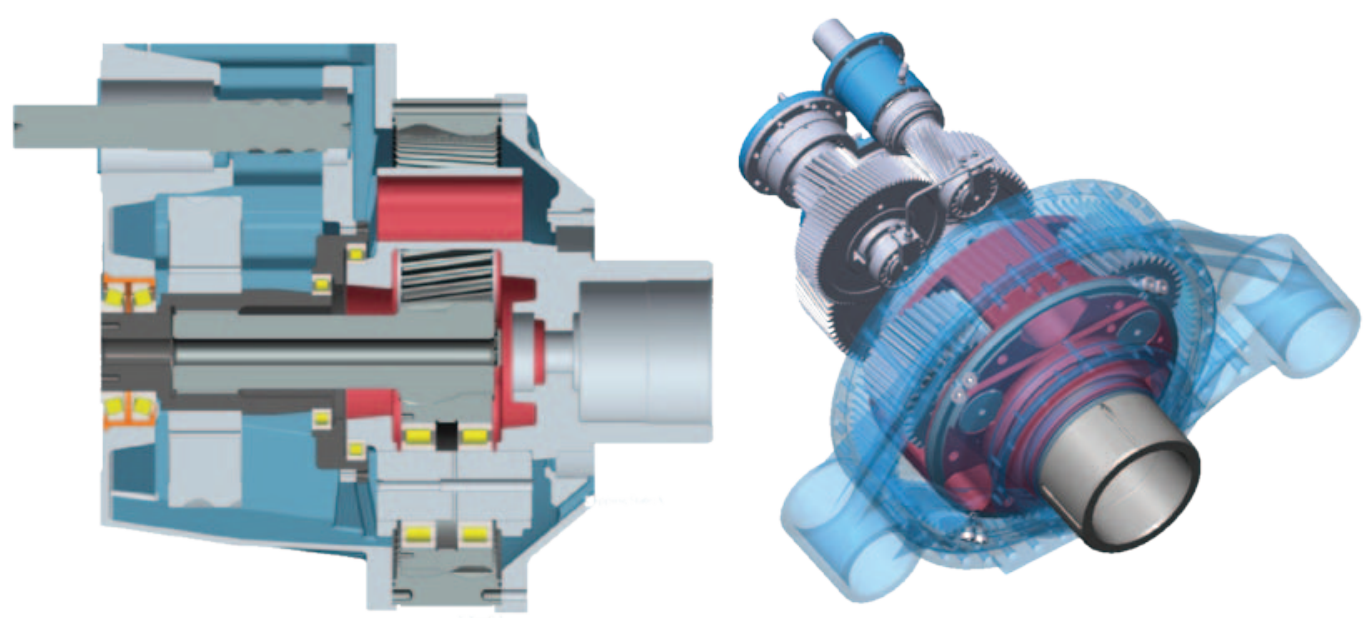

The Gearbox Reliability Collaborative analyzes gearbox designs to improve reliability.

In 2006, the Wind Program launched a Wind Turbine Gearbox Reliability Collaborative (GRC) to focus industry efforts on improving gearbox performance. The goal of the GRC is to validate the typical design process - from the wind turbine system loads to bearing rating - through a comprehensive dynamometer and field-test program on extensively instrumented gearboxes. This design analysis will isolate gaps in the state-of-the-art design process and form a basis for improving reliability of future designs and retrofit packages.

In July 2008, the GRC analysis team, comprising the world's leading turbine manufacturers, consultants, and experts, met for the first time to compare preliminary baseline predictions of geartooth loads and bearing loads. The team's efforts will help the GRC understand where design process gaps and discrepancies exist and help clarify how much detail will be needed to capture relevant design information. All of the meeting's participants agreed that this unique project will prove extremely valuable in terms of increasing the collective awareness of the unique aspects of the wind turbine gearbox-design process.

\section{Validating Performance and Design}

The Wind Program works with industry partners to validate the designs and performance of wind turbines by conducting tests on components and full-scale turbines in laboratory environments and in the field. The data produced by these tests are also used to validate turbine design codes and simulations to improve the turbine design process.

\section{Full-Scale Turbines}

At the NWTC, engineers are installing the two largest turbines ever tested at the laboratory. A GE 1.5-MW and a Siemens 2.3-MW turbine will be erected on the NWTC's eastern perimeter in 2009. These turbines will help researchers improve turbine performance and reliability.

The Siemens 2.3-MW turbine is a late-stage prototype. It features a novel blade design that captures more of the wind's energy, but should not force any more load onto the turbine's moving parts and control systems. It will be heavily instrumented to produce a constant stream of data on aerodynamics, power characteristics, vibrations, system fatigue, acoustics and other key measurements. Siemens is providing the turbine, engineering support, and maintenance from its new R\&D office in nearby Boulder, Colorado. NREL is providing the site, installation services and expertise in field aerodynamics testing, structure and reliability testing, and meteorological analysis.

The GE 1.5-MW turbine will mainly be used as a tool for longterm testing and R\&D. It will be instrumented to collect detailed data that will help researchers address a variety of issues, including wind farm underperformance and premature turbine component failure. In addition, it will be used for educational and outreach purposes.

\section{Drivetrains}

Wind Program engineers at NREL worked with several companies in 2008 as part of the program's efforts to help industry partners validate and improve the performance of wind turbine components. Global Energy Concepts completed tests in the NWTC's 2.5-MW dynamometer test facility on a promising prototype 1.5-MW single-stage permanent-magnet drivetrain. This new component was developed under the DOE WindPACT project and currently is being considered for new utility-scale wind turbine system designs.

Composite Technology Corporation (CTC) worked with NREL to test its new DeWind D8.2 drivetrain for a 2.2-MW wind turbine model that was designed for operation on the 60-Hertz $(\mathrm{Hz})$ U.S. electrical grid. CTC decided to spin test the $60-\mathrm{Hz}$ drivetrain on the NWTC's dynamometer to minimize risk before erecting a full $60-\mathrm{Hz}$ demonstrator wind turbine at a test site in Sweetwater, Texas. The dynamometer tests demonstrated stable and satisfactory operation at power levels ranging from 250 kilowatts $(\mathrm{kW})$ to $2 \mathrm{MW}$. 


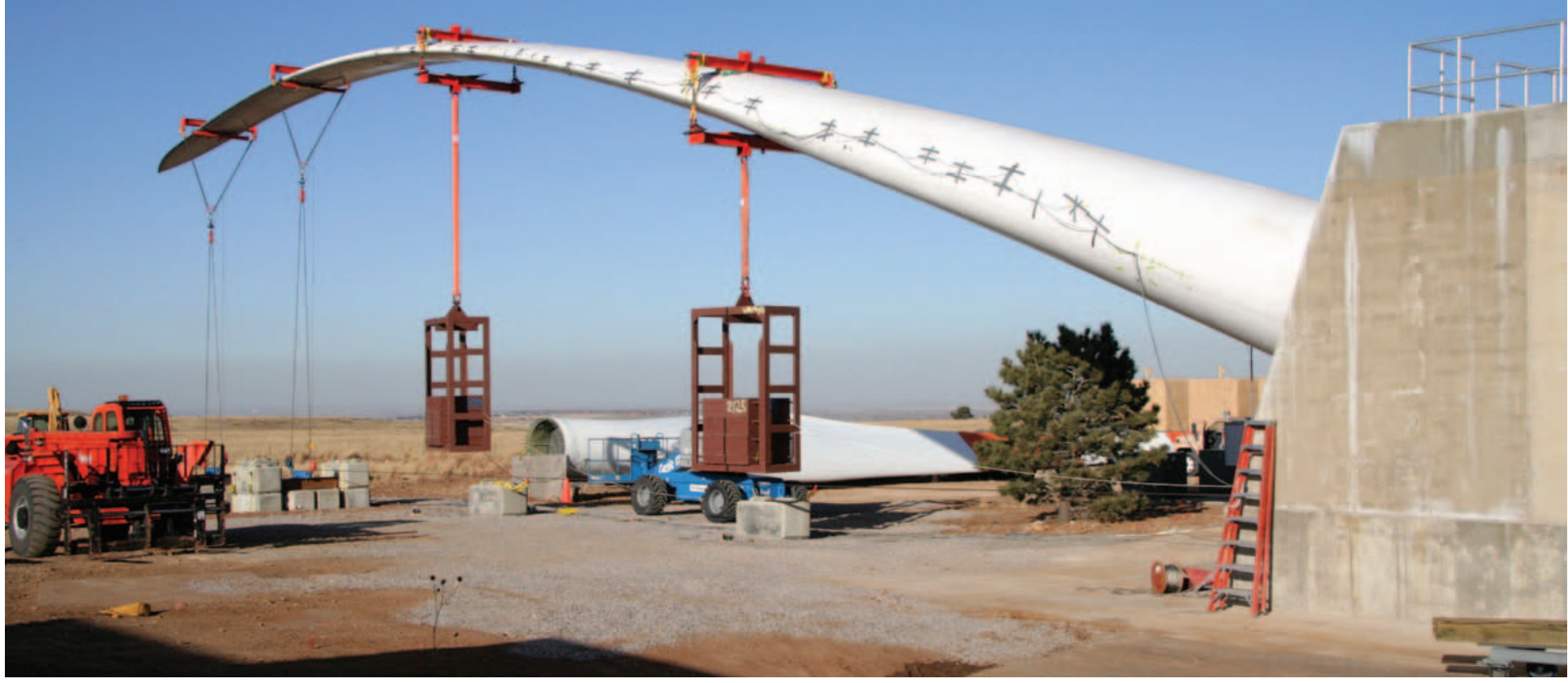

Wind Program researchers at the NWTC conduct structural tests, such as this static test on a 44-m wind turbine blade, for industry partners.

\section{Blade Design and Testing}

To verify the performance of new blade designs and materials, the Wind Program worked with several industry and academic partners in 2008 to conduct structural tests on a variety of blades, including Knight \& Carver's 27-m STAR blade developed with SNL and a 46.2-m blade developed by TPI Composites. The NREL structural testing group also worked with SNL researchers to test the 9-m TX-100 wind turbine blade developed by SNL.

\section{New Blade-Testing Facilities}

In response to the increased industrial activity across North America and the larger blades being deployed on wind turbines, the Wind Program is working with consortiums in Massachusetts and Texas to develop two new blade test facilities. The new facilities will give industry an unbiased, technical environment in which to ensure that the new larger blades meet design and certification standards. Testing these new blades before they are deployed in the field will reduce the financial and technical risks associated with mass production. The new facilities will be capable of testing blades up to 80-m and 100-m long.

\section{Advanced Control Strategies}

Advanced wind turbine control strategies, such as independent blade pitch and generator torque, can increase energy capture and reduce turbine structural loading. Wind Program studies indicate that the performance of large wind technology can be improved if the industry moves toward the use of larger more slender turbine blades placed on taller towers. Designing these large structures to be long lasting and fatigue-resistant-at minimal cost—will be a difficult task. Although the rotor itself can be made more cost effective through innovative control approaches, the entire wind turbine system will benefit as loads are reduced everywhere on the structure.

\section{Developing Design Tools and Simulation Codes}

The wind industry relies heavily on design tools and simulation codes for wind turbine performance, loads, and stability analyses and development. The fundamental codes are comprehensive "aero-hydro-servo-elastic" codes, meaning that they incorporate aerodynamic models, hydrodynamic models (for offshore systems), control system (servo) models, and structural-dynamic (elastic) models in a fully integrated simulation environment. Ancillary tools, such as for data analysis, are also needed to support the design and analysis process.

The Wind Program has developed tools and codes that now are the industry standard for analysis and development for wind turbine designers, manufacturers, consultants, and researchers in the United States and around the world. For example, AeroDyn, an aerodynamics software library developed by NREL and its subcontractors, is widely used by horizontal-axis wind turbine designers for aerodynamic analysis. This analysis includes modeling the wind turbine's performance, stability, and loads.

\section{AeroDyn Upgrade}

In February 2008, NREL held a two-day workshop at the NWTC to kick off an overhaul of the AeroDyn software. With 50 attendees, the high level of interest in the meeting underscored the important role that AeroDyn and the other design codes developed and

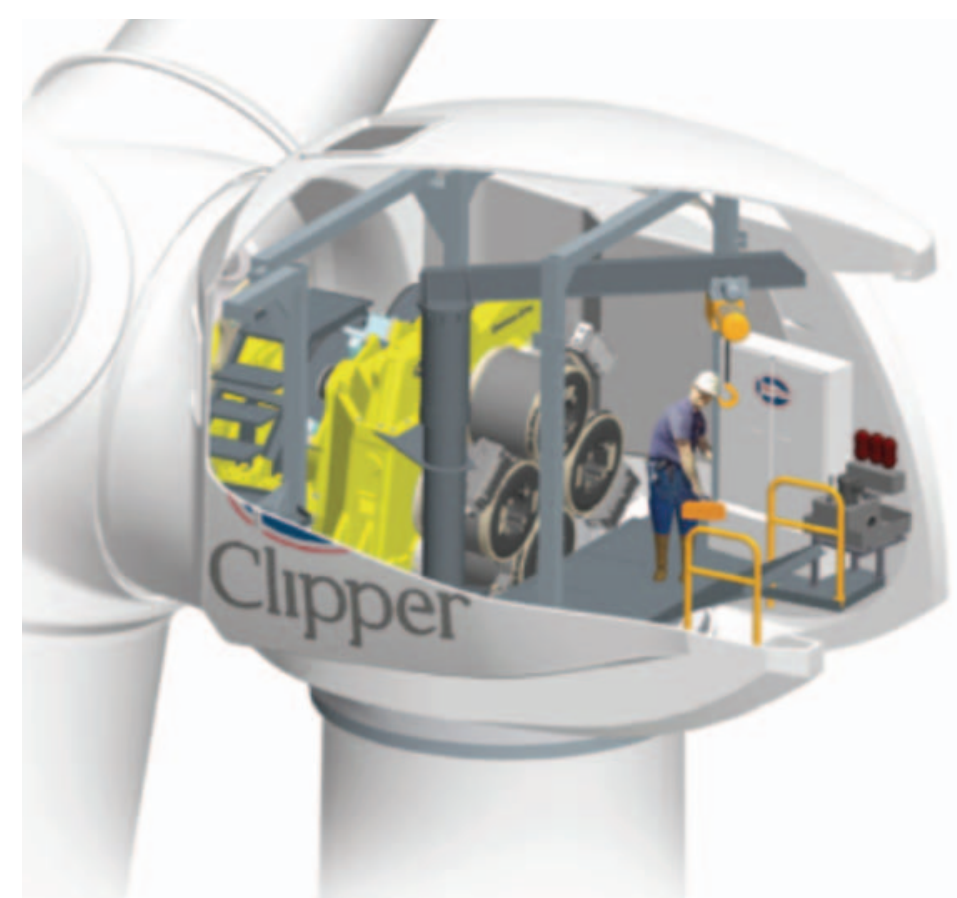

Clipper Windpower produced a prototype of its 2.5-MW Liberty wind turbine after only 3 years of cooperative R\&D with the Wind Program. 
maintained by program researchers play in the wind energy industry. All attendees agreed that limitations in the existing design codes are barriers to the advancement of wind power, and that the improvement of AeroDyn is critical to the successful long-term performance, operation, and reliability of wind turbines. The objectives of the overhaul of AeroDyn are to improve its functionality, readability, and usability; to eliminate errors; to make it easier to include additional aerodynamic theories; and to develop a standardized and streamlined interface to structural dynamic analysis programs.

\section{International Cooperation}

As a member of the International Energy Agency (IEA) Wind Energy Executive Committee, the DOE Wind Program supports international wind energy research efforts by providing operating agents for several IEA R\&D activities or Tasks. The United States participates in the 10 IEA Tasks listed below, is the operating agent for four of the Tasks, and provides technical experts for the Topical Expert meetings held under Task 11: Base Technology Information Exchange.

- Task 19: Wind Energy in Cold Climates

- Task 20: Horizontal-Axis Wind Turbine Aerodynamics and Models from Wind Tunnel Measurements-Operating Agent

- Task 21: Dynamic Models of Wind Farms for Power Systems Studies

- Task 23: Offshore Wind Energy Technology and DeploymentOperating Agent

- Task 24: Integration of Wind and Hydropower Systems-

Operating Agent

- Task 25: Power System Operation with Large Amounts of Wind Power

- Task 26: Cost of Wind Energy-operating agent

- Task 27: Labeling of Small Wind Systems

- Task 28: Social Acceptance of Wind Energy Projects

-Task 29: Analysis of Wind Tunnel Measurements and Improvement of Aerodynamic Models

The program's participation in the IEA Wind Implementing Agreement gives U.S. researchers the opportunity to collaborate with international experts in wind energy, exchange recent technical and market information, and gain valuable feedback for the U.S. industry. For more information on IEA activities, visit the IEA Web site at www.ieawind.org.

\section{A Cooperative Research and Development Agreement (CRADA) with Spain}

The Wind Program is also working with Spain's Centro Nacional de Energías Renovables (CENER) to commission a new facility for testing blades manufactured in Spain. CENER is an industrial technology center and has the mission of identifying, generating, disseminating, and transferring scientific and technical knowledge to the renewable energy sector. Information obtained from CENER will be used to accelerate the development of the program's new blade test facilities in the United States.

CENER also works with program researchers at NREL to verify, validate, and improve wind turbine design, aerodynamic, and acoustic computational codes.

\section{Developing International Standards}

The International Electrotechnical Commission (IEC) oversees committees of researchers and industry representatives that develop international design standards. These standards often dictate design specifications for wind manufacturers that need certification. Researchers from the Wind Program must be involved in these committees to ensure that requirements placed in the standards are fair to the U.S. industry. Many of these standards also specify testing procedures with which the researchers must comply. Knowledge and correct interpretation of the standards therefore is crucial to the DOE testing program. Standards also drive research through the development of tools that can be used by industry to meet future requirements.

The Wind Program is currently involved in the development of 12 IEC standards for large and small wind turbines, all of which are at different stages of maturity. Standards are being developed in the areas that include: turbine safety and design, gearbox requirements, noise, extreme load estimation, power quality, and offshore turbines.

\section{Building Offshore Wind Plants}

Offshore wind energy installations have the potential to make a large impact on meeting the future energy needs of the United States. Of the contiguous 48 states, 28 have a coastal boundaries and U.S. electricity use data show that these states use $78 \%$ of the nation's electricity. When shallow water offshore potential (less than $30 \mathrm{~m}$ in depth) in these states is taken into account, 26 of the 28 states have the wind resources to meet at least $20 \%$ of their electricity needs. Although the U.S. has not yet built any offshore wind plants, projects totaling more than 2,000 MW in capacity have been proposed for locations off the east coast and in the Gulf of Mexico.

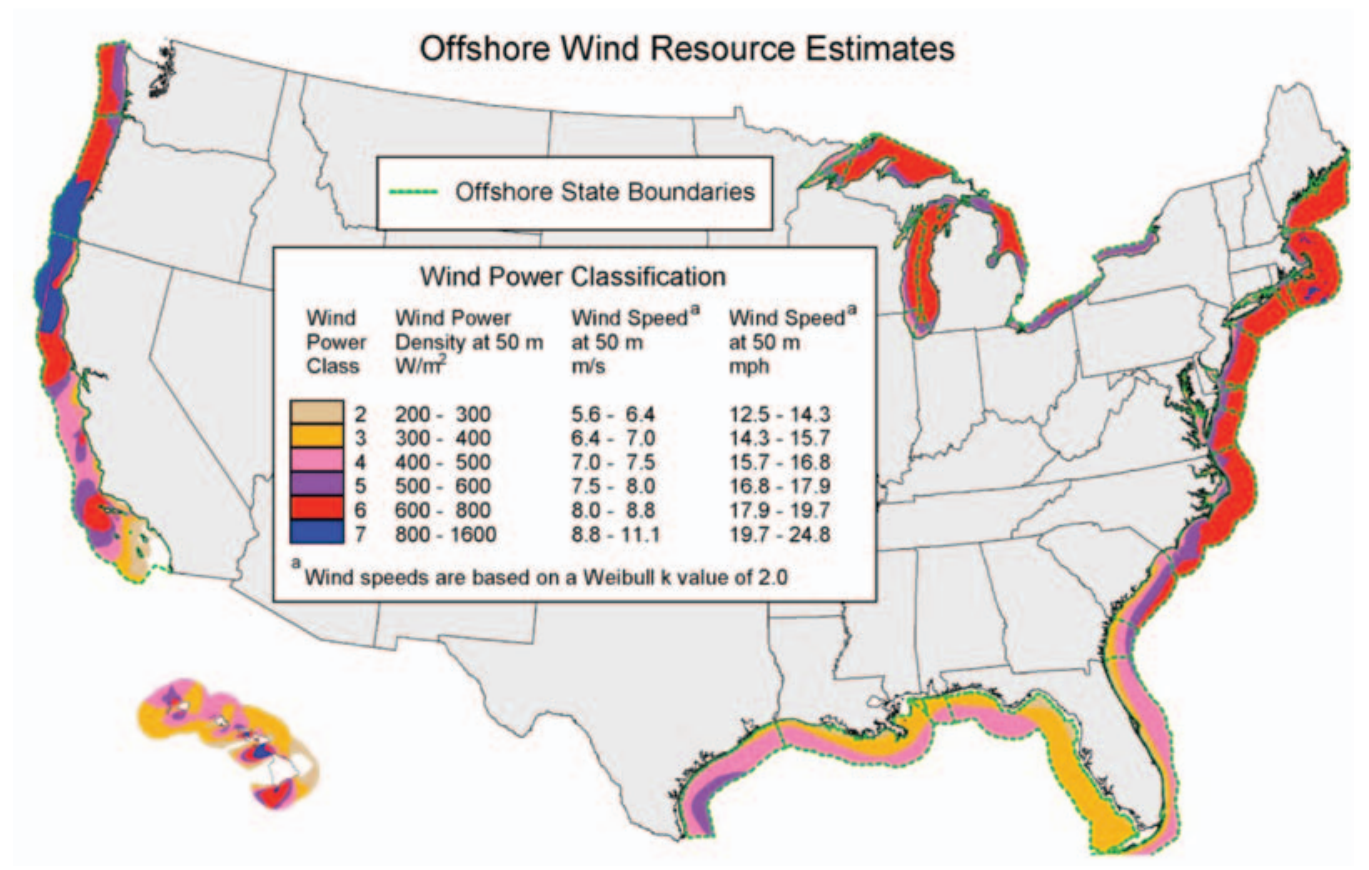

Twenty-six of the 28 coastal states have enough offshore wind resource to meet at least $20 \%$ of their electricity needs with wind energy. 
Commercialization of offshore wind energy faces many technical, regulatory, socioeconomic, and political challenges, some of which can be mitigated through targeted short- and long-range R\&D efforts. Manufacturers can develop larger wind turbines that are capable of producing more energy for offshore applications because they do not have to contend with the same transportation size limits that limit the size of land-based turbines. These turbines must also be more reliable and rugged due to the harsh marine environment. The industry requires comprehensive research assistance to reduce costs for foundations, electrical grids, operation and maintenance (O\&M), and installation and staging.

The Wind Program is working with the Minerals and Management Service (MMS), its national laboratories and industry experts to understand the existing certification standards so they can be applied to U.S. offshore wind turbines. The Energy Policy Act enacted in 2005 granted the Department of Interior's Minerals Management Service (MMS) regulatory responsibility over renewable energy and alternate uses of offshore public lands. For the last 40 years, MMS has regulated the offshore oil and gas industry and other mineral extraction activities in federal waters known as the Outer Continental shelf (OCS).

To ensure the safe installation and operation of wind plants in U.S. coastal waters, DOE and MMS are studying representative technologies and the impact varying marine environments will have on structural reliability, especially where tropical storms are present. As a first step in this development process, the two agencies are comparing the standards developed by the International Electrotechnical Commission (IEC) and other organizations to certify offshore wind turbines in Europe to standards developed by the American Petroleum Institute (API) for offshore drilling platforms to see if they can deliver comparable level of structural safety. U.S. coastal waters are plagued by tropical storms that are not present on coasts of Europe. Therefore, the standards used to design U.S. offshore wind turbines must account for these rare but extreme storm conditions that create wave, current, and wind loads similar to what the offshore U.S. drilling rigs in the Gulf of Mexico experience. Although the API standards developed for offshore U.S. drilling rigs account for these severe storm conditions, they are not applicable in many areas because they were developed for petroleum technologies/structures, which differ greatly from wind turbine structures.

Although some of the standards used by the IEC to certify European offshore wind turbines may be applicable for U.S. applications, most of the offshore wind turbines in Europe are installed in water shallower than $30 \mathrm{~m}$ on fixed-bottom substructures. U.S. coastal waters are much deeper than those found off European

Floating Wind

Turbine Concepts

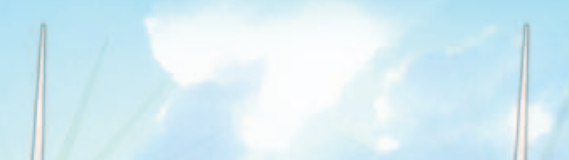




\section{We will transform the way we use energy.}

—President Barack Obama, remarks before signing the

American Recovery and Reinvestment Act, February 17, 2009

\section{GROWING THE MARKET FOR DISTRIBUTED} WIND

$\mathbf{T}$ he term distributed wind technology (DWT) generally refers to single wind turbines installed at the utility distribution level, including installations on the customer side of the meter. These machines range in size from less than 1-kW to 1,000-KW (1 MW) turbines and are often used to offset the customer's electricity costs. In 2008, the industry found a growing domestic market for distributed wind power systems, including small machines for residential and small farm applications and midsize machines for larger agricultural, commercial, industrial, and public facilities.

The small and mid-sized wind turbine markets have unique challenges. For example, product gaps exist for 5-kW, 15-kW, and $100-\mathrm{kW}$ to $1,000-\mathrm{kW}$ turbines. Installations usually consist of single turbines owned by individuals or small businesses that do not have wind engineers on the premises, which makes simplicity in design, ease of repair, and long maintenance and inspection intervals important. Also, because these wind turbines are usually close to workplaces or residences, limiting the amount of sound a turbine emits is critical for market acceptance and zoning approvals. However, small turbines have lower wind speed requirements, therefore more locations can accommodate and harvest wind with this technology.

Wind Program researchers are working to help the wind industry meet growing consumer demands for small turbines (up to $100 \mathrm{~kW}$ ) for residential and small business applications; midsized turbines (100 kW to 1,000 kW) for farms, ranches, and small industry; and locally owned community projects using larger turbines tied to distribution lines. The program also provides technical support and independent testing to the small turbine industry to ensure that safe, credible, and reliable products are available in the U.S. market. 


\section{Assessing the Market for Midsize Turbines}

A midsized-turbine market assessment study, conducted by the DOE Wind Program in 2008, examined significant barriers to the development of distributed wind and the positive and negative factors that affect its economic viability. The report summarized the existing market for $100 \mathrm{GW}$ of currently available commercial turbines and an additional $100 \mathrm{GW}$ of market potential for a new generation of more efficient turbines. The report concluded that several developments are needed for distributed wind to achieve greater penetration, including improvements in the technology, reductions in cost, and greater policy support. The full report, An Analysis of the Technical and Economic Potential for MidScale Distributed Wind, is available to the public through NREL's publication database at http://www.nrel.gov/docs/fy09osti/44280.pdf.

\section{Conducting Independent Testing}

To help industry offer consumers more small wind turbine systems that are certified for safety and performance, the Wind Program at NREL launched an independent small wind turbine test project in 2007. The first four turbines to undergo testing were selected in 2008. These turbines were installed at the NWTC in 2008: Mariah Power's Windspire Giromill machine, a 1.2-kW vertical-axis wind turbine; Abundant Renewable Energy's 442 10-kW turbine; Gaia-Wind's 11-kW two-bladed turbine; and Entegrity Wind System's EW50 50-kW turbine. These commercially available turbines are being tested to standards adopted by the IEC and in compliance with the draft AWEA standards for small wind-turbine systems. The tests, which include power performance, power quality, acoustics, safety and function, and duration, are underway. More information is available at http://www.nrel.gov/wind/smallwind/independent_ testing_videos_text.html.

\section{Regional Test Centers}

Although the NWTC has facilities sufficient for testing up to eight small wind turbines per year, this is not enough to satisfy testing requests from consumers, manufacturers, and state and utility incentive programs. The Wind Program is currently scoping a project to develop Regional Test Centers (RTCs) and defining how these RTCs would operate.

As part of that effort, the program hosted a Small Wind Testing Workshop in 2008. More than 50 people attended the workshop, including representatives of existing and proposed test centers. The workshop provided an opportunity for researchers to coordinate with small wind testing organizations and identify wind turbine test experts across North America that are involved with qualifying or certifying the performance of commercial small wind turbines. Participants from the academic sector, as well as organizations such as the New York State Energy Research Authority, expressed interest in working with the Wind Program to set up their own small wind testing and research centers.

\section{The Small Wind Certification Council}

The Wind Program is also funding and providing technical support for the Small Wind Certification Council (SWCC). The council is developing process and procedures guidance for manufacturers to be able to submit test data and have their turbines certified. Certification by the SWCC will help strengthen the deployment of small wind turbines by increasing consumer confidence that the turbines they purchase will operate as advertised. Manufacturers

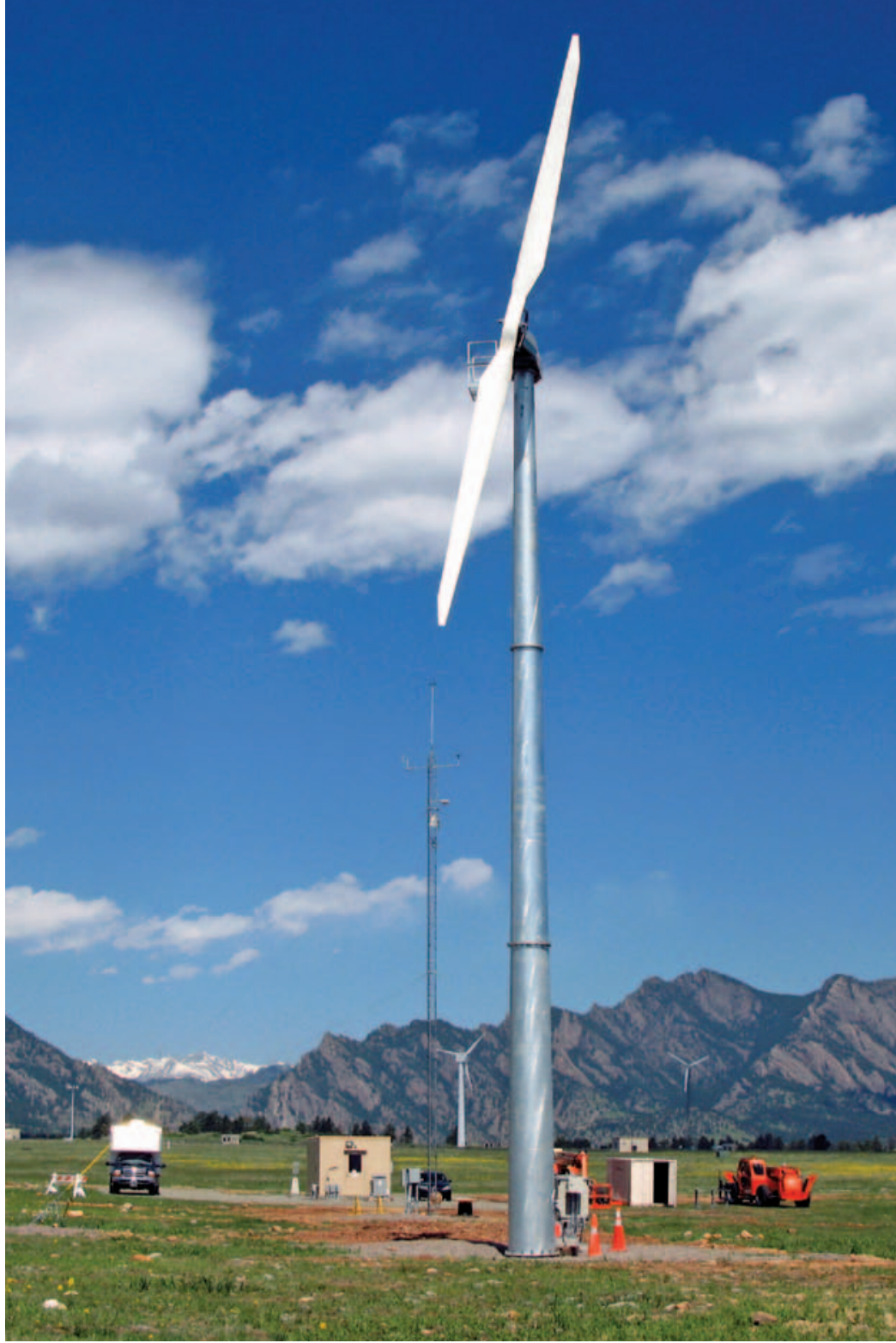

The Gaia 11-kW wind turbine is one of four wind turbines installed at the NWTC to be tested in the Small Turbine Independent Testing project.

also benefit from certification because consumers are more likely to purchase a turbine from a manufacturer that is certified. The availability of certified small wind turbines will also provide greater security to consumers and state-supported programs, further helping to smooth the growth trajectory of the rapidly expanding small wind market.

\section{International Activities}

On the international front, the Wind Program co-hosted the 2008 International Wind-Diesel Workshop in Girdwood, Alaska. More than 170 participants from more than 10 countries participated in discussions about the potential for a combination of wind and diesel technologies to provide power for remote and isolated communities. The expanded interest in the application of wind energy in places such as Alaska, Hawaii, and other isolated communities largely is driven by the rapidly rising cost of diesel fuel. Wind energy technology is seen as one of the key technologies that can be used to reduce the cost of energy in these areas. The meeting was co-organized by the Alaska Energy Authority, the Renewable Energy Alaska Project, and the Wind Energy Institute of Canada. 


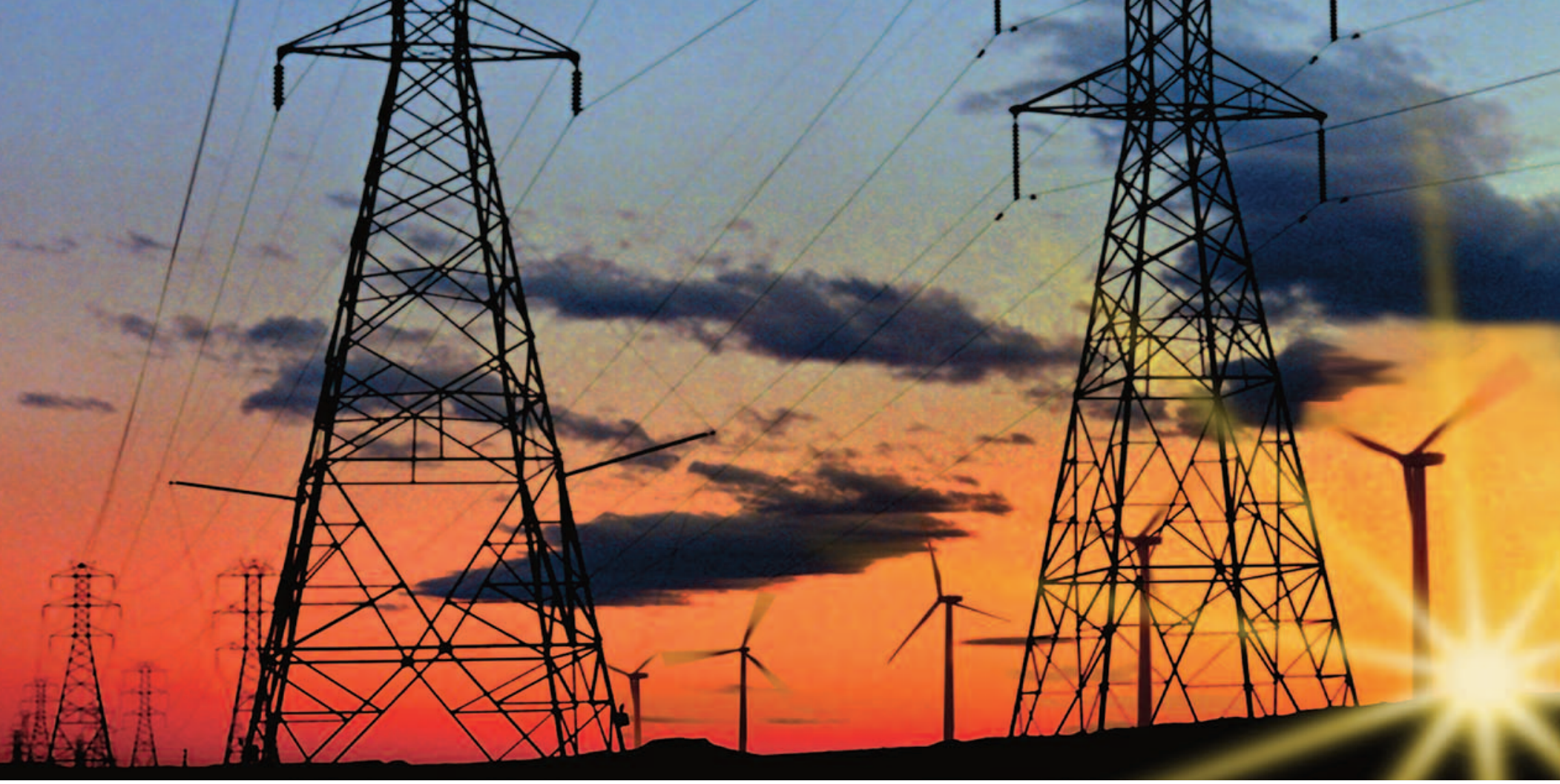

\section{ENHANCING WIND INTEGRATION}

\section{And it's an investment that takes the important first step toward a nationwide [energy] transmission superhighway that will connect our cities to the windy plains of the Dakotas and the sunny deserts of the Southwest. \\ -President Barack Obama, remarks before signing the American Recovery and Reinvestment Act, February 17, 2009}

\section{Understanding Integration and Resource Planning}

The natural variability of the wind resource can present challenges to grid system operators and planners with regard to managing regulation, load following, scheduling, line voltage, and reserves. While the current level of wind penetration in the United States and around the world has provided substantial experience for successful grid operations with wind power, many grid operators need to gain a better understanding of the impacts of wind on the utility grid before they can feel comfortable increasing the percentage of wind in their energy portfolios. The goal of the Wind Program's systems integration research is to address interconnection impacts, electric power market rules, operating strategies, and system planning needed for wind energy to compete without disadvantage to serve the nation's energy needs.

\section{The Renewable Systems Interconnection (RSI) Team}

As the nation moves toward an energy market with greater use of wind energy, it is becoming more important for grid operators to understand how they can reliably integrate large quantities of wind energy into routine system operations. To address this need, DOE tapped the resources of its national laboratories to form an RSI research team. The team includes researchers from Argonne National Laboratory, Lawrence Livermore National Laboratory, Los Alamos National Laboratory, the National Renewable Energy Laboratory, Oak Ridge National Laboratory, Pacific Northwest National Laboratory, and Sandia National Laboratories.
Team members are working with industry partners, university researchers, independent system operators (ISOs), regional transmission organizations (RTOs), the Federal Energy Regulatory Commission (FERC), and DOE's Office of Electricity Delivery and Energy Reliability (OE). The team's charter is to increase the understanding of the true impacts of wind energy on the U.S. electrical infrastructure and to ensure that grid reform measures include provisions for variable generation resources such as wind energy.

The RSI team has participated in several high-penetration utility wind integration studies that demonstrate that significant wind energy generation can be integrated cost effectively into electric grid systems. Scenarios evaluated included penetrations of up to $25 \%$ energy from wind in Minnesota, 33\% renewables in California, and $20 \%$ wind energy capacity in Colorado. At these moderately high penetration levels, these studies found that wind power's variability and uncertainty imposed reasonably low ancillary costs, less than $\$ 5 / \mathrm{MWh}$.

The team is also examining the major areas of the grid known as the Western Interconnection and the Eastern Interconnection. The Western Interconnection stretches from western Canada south to Baja California in Mexico, reaching east over the Rockies to the Great Plains. The Eastern Interconnection reaches from central Canada east to the Atlantic Coast (excluding Québec), south to Florida, and back west to the foot of the Rockies (excluding most of Texas, which has its own interconnection grid). During normal system conditions, all the electric utilities in each interconnection are electrically tied together, operating at a synchronized frequency averaging $60 \mathrm{~Hz}$. 


\section{Western Wind and Solar Integration Study}

The RSI team is working with companies GE and 3TIER to investigate the impacts of significant penetrations of wind and solar on the grid in a large portion of the Western Interconnection. This stakeholder-driven effort includes the statistical analysis, scenario development, and simulation runs that will examine issues such as the geographical diversity of wind, feasibility of megaprojects $(1,000$ MW or greater), and intricacies of balancing area cooperation.

3TIER is using mesoscale models to create wind speed and wind power output time series. The modeling effort covers a very large area and the time series generated covers a period of 3 years. This effort will generate 30,000 simulated time-series data sets of wind power output. This mesoscale modeling effort represents unique 30-MW wind plants, totaling $600 \mathrm{GW}$ of potential wind power capacity. GE will then conduct power system modeling and analysis using these data sets. Results will be publicly available online at www.nrel.gov/wind/systemsintegrarion/.

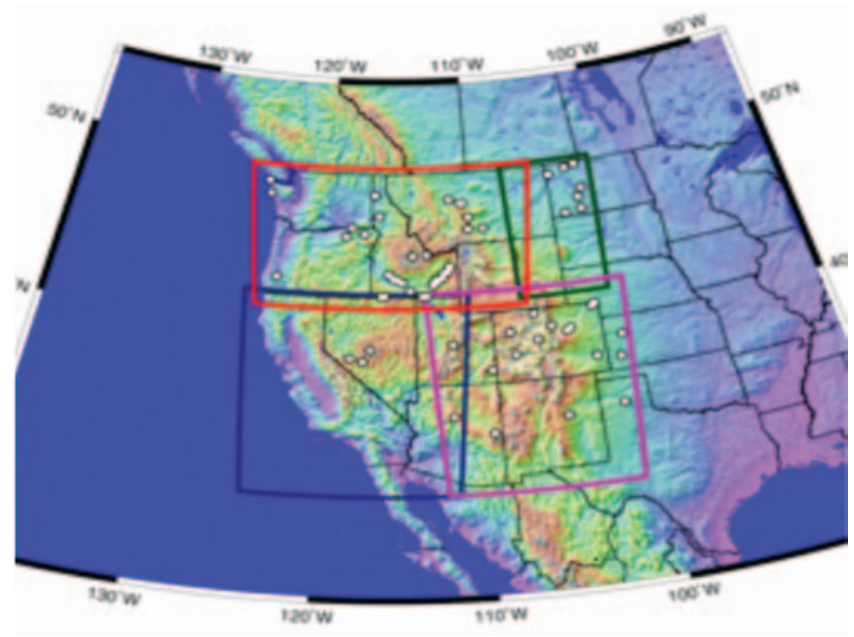

This mesoscale model created by 3TIER will help investigators study the impacts of significant penetrations of wind and solar on the grid in a large portion of the Western Interconnection.

\section{Eastern Wind Integration and Transmission Study}

This investigation - the largest integration study conducted to date-encompasses the ISOs and RTOs in regions covered by the Midwest ISO (MISO), the Midwest Reliability Organization, the Southwest Power Pool (SPP), Entergy, the Tennessee Valley Authority, the Southeast Electricity Reliability Corporation, PJM (PennsylvaniaJersey-Maryland RTO), the New York ISO, and the New England ISO. The company AWS Truewind is conducting the mesoscale modeling, and EnerNex and MISO are carrying out the power system modeling and analysis. This study supports efforts to examine the feasibility of a 765-kilovolt (kV) transmission system that could enhance the interconnections between MISO and PJM and might expand to include the SPP.

\section{North American Electric Reliability Corporation}

The North American Electric Reliability Corporation's Integrating Variable Generation Task Force is currently examining the role of wind energy in system reliability. The task force includes members from transmission operators, reliability regions, and utilities around the United States and Canada. The RSI team began working with the task force in 2008 to ensure that its members have accurate information about the impacts of wind energy on the operation of the nation's energy infrastructure and that wind energy is at the heart of reliability and regulatory discussions.

\section{Forecasting the Wind}

Wind energy industry representatives and utility managers have expressed concerns about the inability to accurately predict wind plant performance. System operators need better projections of how much electricity their wind turbines will generate, and consulting wind forecasts can significantly reduce the uncertainty of wind output. Highly detailed, localized weather forecasts will enable utilities to better integrate electricity generated from wind into the power grid. The forecasts will help operators make critical decisions about powering down traditional coal- and natural-gas-fired plants when sufficient winds are predicted, allowing utilities to increase their reliance on alternative energy and still meet the needs of their customers.

\section{Model Representations of the Wind Resource}

The Wind Program is developing model representations of the wind resource, including seasonal, daily, and hourly data, to better characterize the potential benefits and impacts of wind on system operation and assess transmission availability. The work will provide operators with a tool to anticipate wind generation levels and adjust the remainder of their generation units accordingly. Improved short-term wind production forecasts will let operators make better day-ahead market, operation, and unit-commitment decisions and help real-time operations in the hour ahead. Advanced forecasting systems will also help warn of extreme wind events so that operators can implement a defensive system posture if needed. The seamless integration of wind plant output forecasting - into both power market operations and utility control-room operations-is a critical next step in accommodating large penetrations of wind energy in power systems.

\section{New Forecasting Tools to Pinpoint the Wind Resource}

According to the $20 \%$ by 2030 report, inaccurate wind forecasts and the failure to appropriately integrate and utilize forecast information in market and power dispatch strategies have a direct impact on system reliability and operational costs. To address this challenge, several DOE laboratories are working with utility

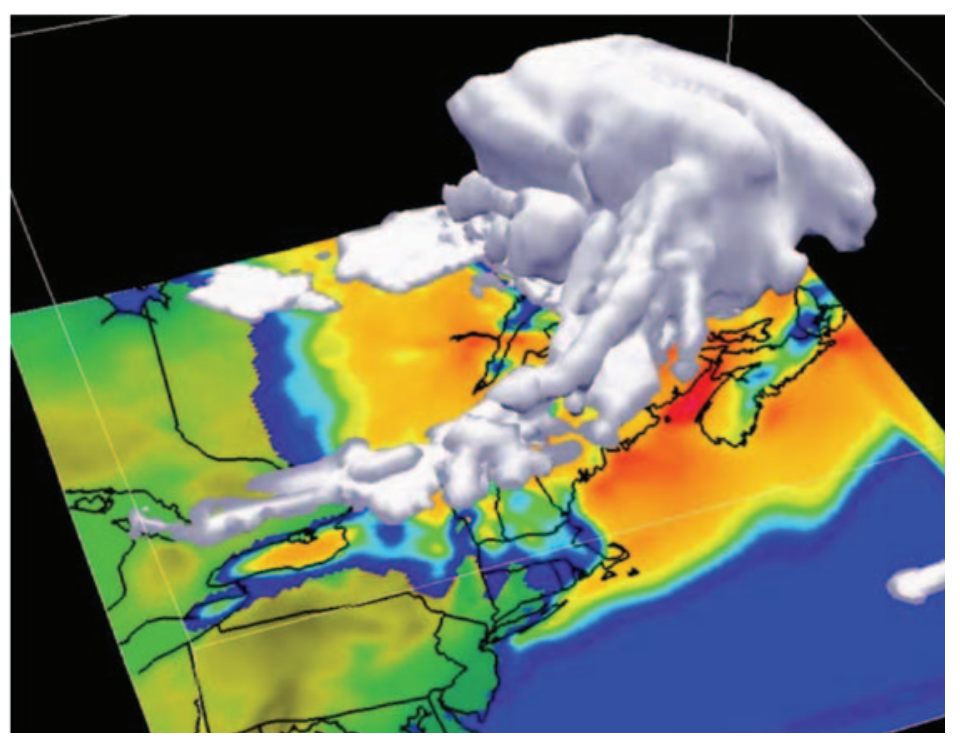

Forecasting models like this model produced by WindLogics, Inc., in St. Paul, MN, can help grid operators anticipate extreme events and improve accuracy on planning, scheduling and system balancing time scales 
operators and other government agencies to improve forecasting methodologies and tools.

Argonne National Laboratory (ANL) is evaluating the current wind power forecasting methodologies and tools to identify their strengths and limitations and then develop new and improved wind forecasting methodology based on the evaluation findings. ANL will then work with grid operators to figure out how wind power plants and power systems can incorporate these advanced wind forecasting technologies into their operations.

Lawrence Livermore National Laboratory (LLNL) is working with forecast modelers and system operators to improve short-term wind energy modeling capabilities and to design an interface environment for system operators based on control room operations and organizational knowledge. LLNL is also analyzing data collected from meteorological towers and SODAR installations and will use the results of their analysis to recommend advanced forecasting techniques that will enable operators to better anticipate wind power generation.

The National Renewable Energy Laboratory (NREL) is working with Xcel Energy and the National Center for Atmospheric Research to demonstrate the next generation of forecast modeling capability, coupled with seamless integration of forecast information into the control room operations. NREL is also working with the Bonneville Power Administration (BPA) and Xcel to improve steady-state wind energy predictions by assessing the latest probabilistic distribution forecasts and neural network analysis techniques used to evaluate wind plant operational anomalies.

Pacific Northwest National Laboratory (PNNL) is working with BPA to enhance wind and load forecasting models and develop probabilistic tools. These tools will enable system operators to better manage wind variability by integrating wind forecasts into the load following process within the energy management system.

\section{"Storing" the Wind}

Research conducted for the $20 \%$ Wind by 2030 report shows that wind's variability need not be a barrier to its incorporation as an option in national energy portfolios. With the continuing evolution of the U.S. electrical system and expansion of electricity markets, wind generation can reliably supply $20 \%$ of the U.S. electricity demand. However, as increasing regional penetration levels of wind are considered, Wind Program researchers are examining a variety of technologies, including storage that could increase system reliability when high levels of variable alternative energy sources such as wind are incorporated into the grid.

Various technologies offer different levels of efficiency, rate of discharge, and time of storage at different costs. The Wind Program's $\mathrm{RSI}$ team is developing a flexibility supply curve to examine the various options for accommodating variable resources and their cost ranges. To develop the curve, team members are examining capacity, energy, and ancillary services values in different market structures using actual market price dynamics. The team is also examining different storage technologies with regard to capacity, discharge rate, and estimated costs.

As part of this effort, the Wind Program is conducting a study in the Upper Midwest that examines the technical and economic feasibility of combining utility-scale wind generation with compressed-air energy storage. The study includes wind resource characterization; grid characterization, analysis, and benefits; storage options; turbo machinery assessment, facility staging and integration; government and public strategies; and economic evaluation.

The DOE Wind Program is also working with the European Union to benchmark the requirements for storage components in renewable energy systems (RES). The goal of this collaboration is to create a database of the operation of components for renewable energy storage systems.

\section{Wind Resource Assessment and Validation}

Achieving $20 \%$ wind energy by 2030 depends on expanded wind power markets and supportive public policies. In order to expand the markets, developers must first identify the areas that show the greatest potential for growth. Wind resource assessments validated at 50-m height have facilitated the rapid growth experienced by the wind power market over the last decade and provided a sound foundation for public policy initiatives to move forward, including state-level renewable portfolio standards. As wind turbines become taller, they will be able to access the wind resources at $100 \mathrm{~m}$ and above, and these resources show even greater potential for expanding wind power markets. Even market areas with mediocre wind resources at $50 \mathrm{~m}$ could experience significant growth through resources validated at $100 \mathrm{~m}$.

Measured wind data are critical to validating 100-m wind resources. Validated wind resources can also help researchers develop wind plant power curves for use in integration studies; improve wind power forecasting; validate, calibrate, and improve mesoscale models for use in integration studies; and understand microeffects.

To collect the data needed to validate these resources, the DOE Wind Program is procuring data from existing tall towers and forming strategic partnerships to utilize existing wind data measurements and networks that include thousands of existing communication towers. The program is also investigating the use of SODAR to perform wind feasibility assessments.

The Wind Program at Oak Ridge National Laboratory is developing an archive for wind resource data that will enable a broad range of users to perform a more rapid analysis of wind energy potentials by allowing the entire user community to develop a common, shared information resource.

\section{Wind Integration Modeling}

Analytic studies and scenario modeling are illuminating the necessary pathways to $20 \%$ by 2030 . The Renewable Energy Deployment System (ReEDS) model developed by Wind Program researchers at NREL is the principal analytical tool used to model scenarios for the generation capacity and transmission infrastructure expansion in the $20 \%$ report. To ensure greater model fidelity, program researchers are expanding their analysis of the $20 \%$ wind integration scenario to supplement the transmission infrastructure expansion aspect of the report, identify potential congestion and reliability issues that could result from the optimized expansion plan, and improve the treatment of transmission within the WindDS model.

Researchers at SNL are developing multilevel engineering models of local and national electric grids with wind generators organized into virtual power plants of increasing scale. These models will be tailored to developing new in-time coordination infrastructures based on distributed intelligent control systems installed on generation, transmission and load elements, with particular emphasis on capturing the emerging aspects of Smartgrid technologies. 


\title{
INCREASING WIND ENERGY DEPLOYMENT
}

\author{
We will act not only to create new jobs, but to lay a new foundation for growth.
}

—President Barack Obama, Inaugural Address, January 20, 2009

\begin{abstract}
$\mathbf{W}$ hen DOE launched the Wind Powering America (WPA) effort in 2000, the United States had a total of only 2,500 MW of installed wind capacity, and only four states had more than $100 \mathrm{MW}$ of installed wind capacity. Today 22 states have more than $100 \mathrm{MW}$ of installed wind capacity, and by the end of the decade, more than 30 states will have passed the 100-MW milestone. The 100-MW milestone is considered significant because the first $100 \mathrm{MW}$ are always the most difficult to achieve. The state's government officials and community leaders must first recognize the benefits of wind energy and then develop an expanded vision of a more economically and environmentally secure and sustainable future. Then they must gain public support and develop the skilled labor force required to develop, build, and operate the state's first wind plants.
\end{abstract}

\section{Focusing on State and Regional Activities}

To help increase wind energy deployment in each state, WPA team members work on state and regional levels to promote wind energy, placing an emphasis on states with good wind resource potential but little wind energy development. On the state level, team members work with community members to form wind working groups in each state. Group members include landowners and agriculturalsector representatives, county commissioners and rural-development specialists, utilities and regulators, colleges and universities, advocacy groups, and other state and local groups. WPA currently has 33 state Wind Working Groups. These working groups form strategic alliances to communicate wind's benefits and challenges to state stakeholders. Through the efforts of the Wind Working Groups, stakeholders have acquired timely and accurate information on the current state of wind technology, economics, wind resources, economic development impacts, policy options, issues, and barriers to wind development in their regions.

Because many of the most challenging wind energy issues are regional in nature and also because the states can learn from the experiences and best practices of others in their region, WPA is also working to develop Regional Wind Energy Institutes (RWEls). During 2008, WPA managed three Regional Wind Energy Institutes (RWEls) to educate and train stakeholders to present the wind energy story to state stakeholder groups. The goal of the RWEls is to provide accurate and current information to members of state wind outreach teams that are actively engaged in furthering wind power development by educating key constituents in their respective states.

Each RWEl holds an annual 1- or 2-day training session in their region. Sessions include a wind industry updates, updates on state progress and challenges, and presentations given by national experts on issues of regional importance. Each RWEI also hosts three to four Webcasts per year to provide tips on how to present current topics and to provide an update session following the annual Wind Powering America Summit.

Each year, WPA hosts an annual summit that brings members of its state and regional working groups together with other wind industry stakeholders and government agencies to exchange information and to learn new methods for mitigating barriers to wind energy development. In 2008, more than 140 members of national and state public- and private-sector organizations from 36 states and Canada attended the 7th Annual WPA All-States Summit in Houston, Texas.

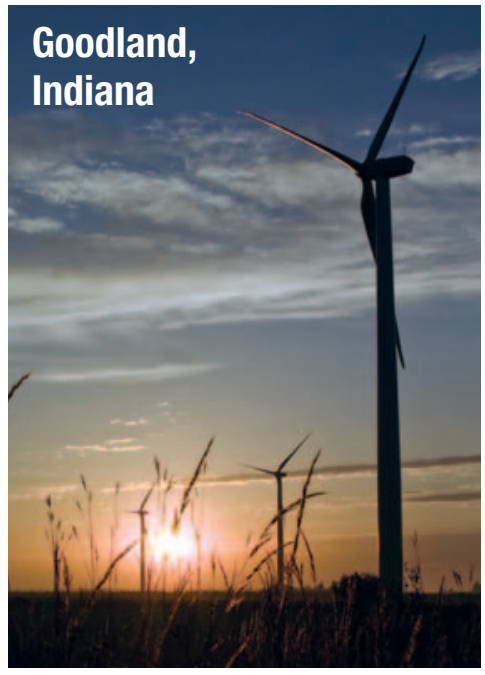

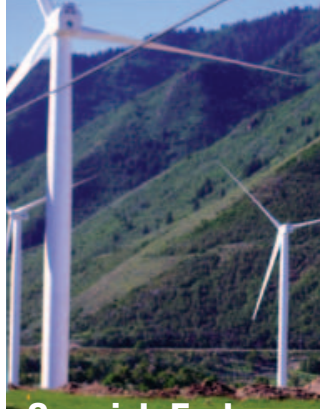

Spanish Fork, Utah.
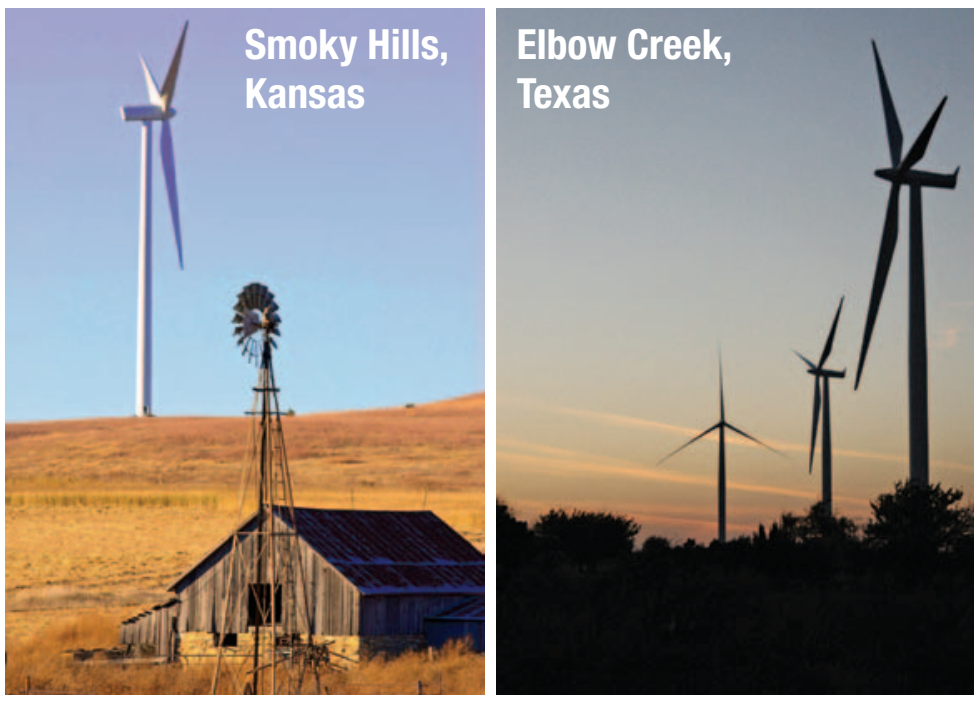

2008 WInd Energy Projects

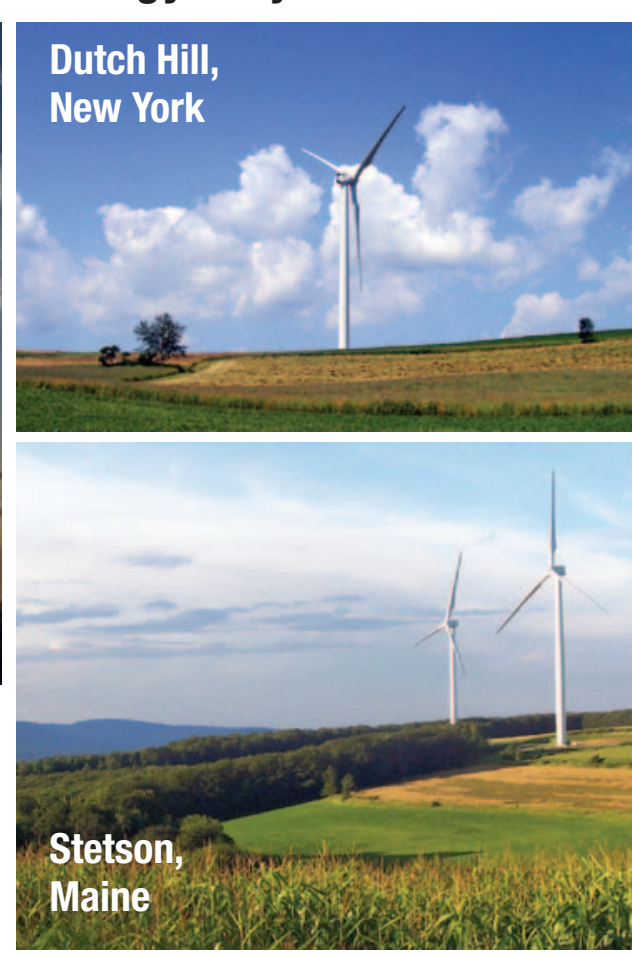




\section{Boosting Rural Economic Development}

In the decade preceding 2030, the $20 \%$ scenario would support 100,000 jobs in associated industries such as accountants, lawyers, steelworkers, and electrical manufacturing, and it will generate much needed income for rural communities. Many of the construction and operation jobs would provide a boost to rural communities because most of the wind plants will be located nearby. Farmers and landowners would gain more than $\$ 600$ million in annual landlease payments and regional governments would gain more than $\$ 1.5$ billion annually in tax revenues by 2030 . Rural counties can use these taxes to fund new schools, roads, and other vital infrastructure, creating even more jobs for local communities.

To educate rural

stakeholders about the benefits of wind energy development, WPA works with rural community leaders, local and national representatives of the U.S. Department of Agriculture, state and local officials, the Farm Bureau, the Farmers' Union, 25×'25 (a group of volunteer farm workers with a goal to obtain $25 \%$ of the nation's energy from renewable resources like wind, solar, and biofuels by the year 2025), the American Corn Growers Foundation (ACGF) and other growers' associations, agricultural schools, the National Association of Counties (NACo), and local financial communities. WPA team members also perform economic development analyses that examine the

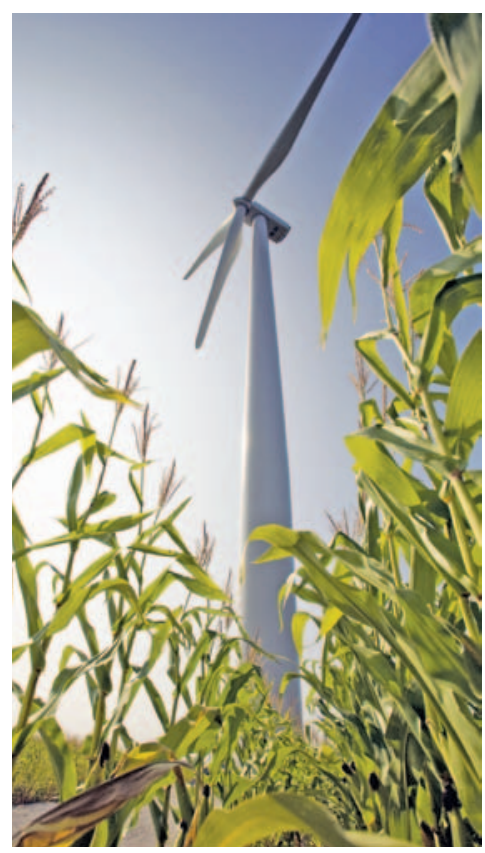

WPA works with agricultural associations such as the American Corn Growers Foundation to educate rural communities about the benefits of wind energy development. impacts of wind versus coal-fueled power production and the impacts of large wind plants in a given region.

\section{Accelerating Industry Growth Through Power Partnerships}

To further encourage the incorporation of wind in the nation's energy portfolios, WPA provides information to and partners with utilities and utility groups such as the American Public Power Association (APPA) and the National Rural Electric Cooperative Association (NRECA), and the Utility Wind Integration Group (UWIG), and power administrations such as Bonneville Power Administration (BPA) and the Western Area Power Administration (WAPA). Power partnership activities include cosponsoring wind-energy meetings, conferences, and workshops; developing wind energy grid-impact models; developing and distributing technical and market-specific information; and providing technical assistance for wind energy project start-ups. In recognition of the efforts of its utility partners, DOE presents two national annual awards: Wind Cooperative of the Year (in conjunction with NRECA), and the Wind Municipal Utility of the Year (in conjunction with the APPA).

\section{Power Partnership Awards}

In 2008, the Aspen Municipal Electric Utility in Aspen, Colorado, received the Municipal Utility of the Year Award for its leadership, innovation and ongoing commitment to incorporating wind power into its portfolio. In 2009, the Wind Energy Program and NRECA recognized Wolverine Power Supply Cooperative as the 2008 Wind Cooperative of the Year at the NRECA TechAdvantage Conference in New Orleans, Louisiana. The award honors the Michigan cooperative for its vision and leadership in developing the state's first \$94 million Harvest Wind Farm in Huron County.

\section{Bringing Wind Power to Native Americans}

The United States is home to 2.4 million Native Americans living on 96 million acres of tribal lands. The Native American unemployment rate is double the national average, $14.2 \%$ live without electricity - and those who have electricity often must pay more than $20 \%$ of their monthly income on power costs. Wind Program researchers have estimated that the 96 million acres of tribal lands in the United States could provide 14\% of the nation's annual electricity demand while providing electricity and revenue to the reservations. Some of the issues that must be resolved before these resources can be fully realized include the lack of wind resource data, tribal utility policies, perceived developer risk, limited loads, investment capital, technical expertise, and transmission to markets. To empower tribal leaders to make decisions about establishing wind energy on their lands, WPA provides a wide range of technical assistance and outreach activities to more than 20 tribes in 13 states.

Of the 93 tribal projects funded by WPA since its inception in 2002, many were cost-shared with Native American organizations. In 2008, the program provided wind monitoring assistance on tribal lands in South Dakota, Massachusetts, New York, and Minnesota and supported meetings, conferences, and outreach sessions in Colorado, California, South Dakota, and Montana. In June 2008, the Lakota Nation celebrated the installation of a $65-\mathrm{kW}$ Nordtank turbine that supplies 120 MWh of electricity per year to the Pine Ridge Reservation radio station.

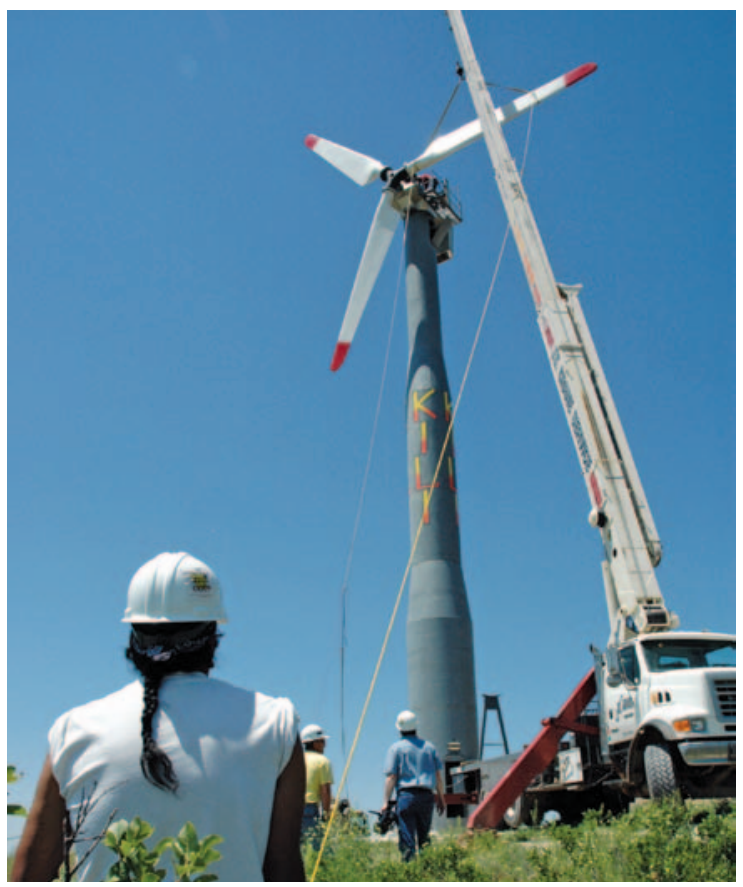

The Lakota Nation in South Dakota celebrated the installation of its $65-\mathrm{kW}$ Nordtank wind turbine. 


\section{Learning about Wind for Schools}

With its Wind for Schools project, WPA is engaging rural America at the grassroots level to develop a wind energy knowledge base. The project's objectives are to engage rural school teachers and students in discussions about wind energy; educate college students about wind energy applications to equip the students to work in engineering positions in the growing U.S. wind industry; and to introduce wind energy options to rural communities to stimulate discussion about wind energy benefits, challenges and deployment solutions.

In the first full year of implementation (2008), WPA made strong progress in the Wind for Schools project and attracted a great deal of national interest and press. During the fall semester, the Wind Application Centers (WACs) at Colorado State University, Boise State University, Kansas State University, South Dakota State University, Montana State University, and the University of Nebraska taught engineering classes that incorporated wind technology and supported the development of vibrant wind energy educational programs. Through the WACs, the program also saw its first university graduates enter the wind workforce, a key milestone in the process of training future generations of wind energy leaders. The program also saw strong implementation of Wind for Schools systems at host K-12 schools, especially in Kansas and Montana. Montana held the first Wind for Schools teacher training workshop, instructing teachers in the wind-energy curricula developed by the National Energy Education Development (NEED) project in partnership with AWEA.

The WPA team continues to develop curricula for all education levels. Through the program's collaboration with the NEED Project and AWEA, a science discovery lesson plan is being developed through which data from each wind turbine can be used to conduct expanded science-based K-12 projects. Additionally, the WPA team is working closely with each of the WACs and Southwest Windpower (a small wind turbine manufacturer) to develop a seamless method to collect wind turbine performance and resource data to be used in $\mathrm{K}-12$ and university curricula. WPA staff also initiated a wind experts video series (expected to be completed in 2009), which collects recorded lectures given by wind energy experts to be used as part of the university programs, providing reallife experience in the development of wind energy projects. The program also implemented the procurement of measurement towers for the Wind for Schools project. The measurement towers allow wind resources to be measured at potential candidate sites while enabling WAC students to implement resource measurement programs and study data assessment, key skills in wind project deployment.
In 2009, each WAC will expand current activities to engage three to five host schools per state, leading to the installation of small wind turbines and the implementation of science-based wind energy curricula at numerous K-12 schools through the NEED Project wind curricula teacher training program. The Wind for Schools project also plans to implement an auxiliary program that will enable host schools and state programs interested in initiating activities using the Wind for Schools model but using locally available non-DOE funds to formally participate in the DOE Wind for Schools project. Any material developed can be applied not only to partner states, but also to other organizations from individual schools, school districts, or state energy offices that may not be formally aligned with Wind for Schools.

\section{Evaluating the Wind Resource}

Wind developers require an estimate of how much wind energy is available at potential project sites. Although wind resource maps developed in the late 1970s and early 1980 s gave reasonable estimates of areas in which good wind resources could be found, new tools and data available from satellites and remote sensing devices are enabling researchers to produce far more accurate and detailed wind maps.

Using highly accurate GPS mapping tools, satellite, weather balloon, and meteorological tower data, combined with muchimproved numerical computer models, the DOE Wind Program is working with U.S. companies to produce higher resolution maps of resources at higher heights above ground for the United States and other countries. The greater horizontal resolution of these maps (1 km or better) allows for more accurate siting of wind turbines and has led to the recognition of higher-class winds in areas where no such winds were thought to exist.

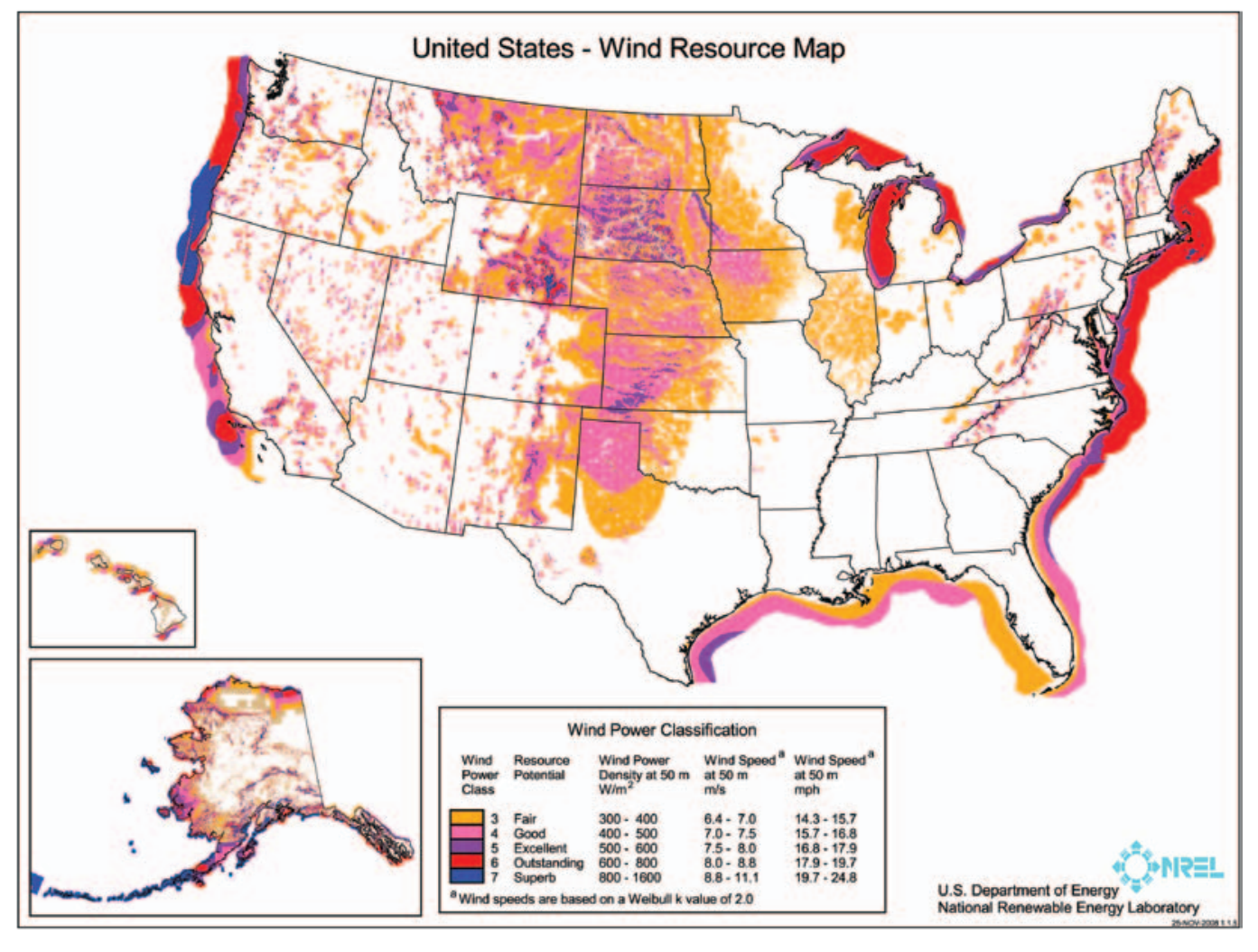

The United States has more than 8,000 GW of available land-based wind resources that could be captured economically. 


\section{Understanding Wind-Radar Interactions}

Wind-radar interactions drew the attention of researchers and developers in 2006 when the U.S. Department of Defense discovered that wind turbine structures and rotors can reflect radar signals, causing clutter on radar screens that can interfere with accurate readings. Although the ensuing research found that in the majority of cases, interference is not present, is not deemed significant, or could be readily mitigated, navigational and defense radar interference is an issue that must be addressed by wind developers. Understanding the extent of a wind installation's radar interference potential and developing mitigation techniques is complicated because the amount of interference depends on turbine height, rotor sweep area, blade rotation speed, and the landscape surrounding a wind energy project. Wind Program researchers at the Idaho National Laboratories and SNL are working with the Department of Defense and the Federal Aviation Administration to determine the extent of windradar interactions and develop measures to mitigate the possible effects of wind turbines on civilian and military radar systems.

\section{Understanding Wind-Wildlife Interactions}

As with any human activity, the construction and operation of wind energy installations will impact the natural environment. Wind turbines can impact bird, bat, and other wildlife populations, depending on the project's location. To help resolve wind-wildlife interactions, the Wind Program is working with the U.S.

Fish and Wildlife service on the Wind Turbines Guidelines Advisory Committee. The committee's 22 members represent the varied interests associated with wind energy development and wildlife management, including federal and state agencies, conservation groups, Native Americans, wind energy developers, and utilities. The objective of this committee is of provide the Secretary of Interior with recommendations for developing effective measures to avoid or minimize impacts to wildlife and their habitats related to land-based wind energy facilities.

The program also supports two collaborative wind-wildlife research efforts, the Grassland Shrub Steppe Species Collaborative and the Bat and Wind Energy Collaborative (BWEC).

The Grassland Shrub Steppe Species Collaborative (GS3C), established in 2005 by DOE through its National Wind Coordinating Collaborative (NWCC), includes representatives from state and federal agencies, academic institutions, nongovernmental organizations, and the wind industry. The goal of this 4-year research collaborative is to identify the impact, if any, of wind installations on grassland and shrub steppe avian species such as the lesser prairie chicken.

DOE is also working with BWEC, which includes the Bat Conservation International (BCI), the U.S. Fish and Wildlife Service, and the American Wind Energy Association, to understand the impacts of wind turbines on bat populations, with a focus on wind plants located in the eastern states where unexpectedly high number of bat fatalities have occurred. Specific tasks of this research effort include validating and refining the accuracy of methods and metrics to predict post-construction wind plant impacts on bats based on preconstruction assessments, and developing and field-testing an acoustic deterrent to discourage bats from entering wind facilities.
In January 2008, the Wind Program co-hosted a workshop in Austin, Texas, that brought together some of the world's leading bat scientists and representatives from the wind industry and state and federal agencies. The workshop's 50 participants shared information and worked to find solutions that support the continued growth of wind energy production in concert with preserving bats and their habitats.

The Wind Program is also working with the U.S. Geological Survey and Montana State University to investigate whether artificial intelligence can be used to detect birds in NEXRAD data. The objective of this research is to develop algorithms that can differentiate biological from inorganic echoes in the NEXRAD data which then can be used to identify migratory flyways.

\section{TEAMing Up for Change}

The Transformational Energy Action Management (TEAM) Initiative is a plan developed by DOE to dramatically transform the Department's energy, environmental, and transportation management. The initiative is designed to end the practice of incremental energy improvements, and institute transformative management practices that put DOE on a path to true leadership in the arena of sustainable energy and environment management. By fundamentally transforming the way DOE manages energy use in its facilities, the TEAM initiative will leverage every possible public and private resource to improve performance and reduce energy and water costs at DOE facilities over the next few years. Moreover, the Initiative will contribute to the nation's energy and economic security and save taxpayer dollars through guaranteed cost savings.

WPA supports the TEAM initiative through a variety of efforts. NREL staff conducted site visits to examine wind potential at SNL, ANL, and Fermi National Accelerator Laboratory. A preliminary wind-feasibility study using existing wind data was completed for Argonne and Fermi. As part of this effort, NREL sent meteorological (MET) towers to SNL and INL to augment MET towers already installed by the labs. NREL is also loaning its mini-SODAR to the INL to augment the wind resource assessment as part of the TEAM Initiative. SNL is actively participating in the TEAM Initiative through the analysis of an onsite $30-\mathrm{MW}$ wind farm that would tie into the SNL distribution network and be utilized by both SNL and Kirkland Air Force Base.

DOE and WPA team members at NREL worked with the Renewable Energy Research Laboratory at the University of Massachusetts, the Army Environmental Command Impact Area Groundwater Study Program, the Air Force Center for Engineering and the Environment, and the U.S. Coast Guard Air Station at the Massachusetts Military Reservation (MMR) on Cape Cod to conduct a Federal Wind Energy Applications Technology Symposium at MMR in May 2008. Forty people attended, including representatives from about 20 federal agencies. Two days of intensive wind energy technology discussions and lectures were followed by a day of presentations from various sectors of the wind industry, including manufacturers, developers, meteorologists, environmental assessors, and financiers.

In July 2008, PNNL hosted an Army Energy Summit in Richland, Washington. Energy managers from 20 U.S. Army bases convened to learn about renewable energy technologies suitable for their locations and applications. A contingent of WPA team members made presentations on wind energy and worked directly with the energy managers to formulate wind development plans for their bases. 


\title{
ENSURING LONG-TERM INDUSTRY GROWTH
}

\author{
[The New Energy for America] plan will finally spark the creation of a clean \\ energy industry that will create hundreds of thousands of jobs over \\ the next few years, manufacturing wind turbines and solar cells. \\ —President Barack Obama, Address to Department of Energy staff, February 5th, 2009
}

GE Wind Energy's 1.5-MW turbines on a wind plant in Searville, Kansas

D OE's Wind Program has worked with industry for more than 25 years to advance both large and small wind energy technologies. For large wind technologies, these industry partnerships have succeeded in increasing capacity factors while dramatically reducing costs. Advances in small wind technology have produced quieter and more reliable systems that are easier to install and cost less to operate.

Many of the technologies developed under the program in the past have moved into the marketplace to become commercial successes, and in 2009, the program will begin exploring the next generation of machines through a CRADA with American Superconductor Corporation (AMSC). This project will evaluate the economics of an advanced 10-MW wind turbine. The new design will incorporate a direct-drive generator that utilizes high-temperature superconductor wire instead of copper wire for the rotor of the generator. According to AMSC, the new superconductor technology will greatly reduce the size and weight of 10-MW class systems thus allowing for greater deployment of these larger systems on land as well as offshore. The size of the systems installed today is limited to approximately $6 \mathrm{MW}$ by land transportation and tower installation constraints.

In addition to helping industry advance wind technologies, the program has worked to increase public and utility acceptance of wind energy by developing methodologies to reliably integrate wind energy into our nation's infrastructure and providing accurate up-to-date information. The phenomenal growth of the wind energy industry over the last decade can be related at least in part to its gaining popularity. Opinion polls conducted nationwide show that the public strongly supports the development of clean energy alternatives, and wind energy is now the fastest growing, least expensive new source of electricity generation. The connection between wind energy industry growth and its increasing popularity is due, in part, to an increase in public awareness. People are becoming more knowledgeable about wind's benefits, and facts are dispelling myths because nonprofit organizations and government programs like Wind Powering America are getting the word outwind energy works.

Although the technology and industry as a whole have come a long way, achieving $20 \%$ wind energy by 2030 will require comprehensive R\&D to address a broad spectrum of challenges facing industry today. The machines need to be more reliable, capture more energy, and cost less to produce and operate so that wind energy can compete with traditional fuel sources in the marketplace. The nation's transmission infrastructure needs to be expanded and upgraded so that clean alternative energy sources like wind can be efficiently transported to our nation's load centers. Manufacturing facilities need to increase and improve their production processes to keep pace with demand, and the skilled workforce needed to fill the jobs generated by this growth needs to increase. Finally, barriers created by misconceptions and a lack of understanding need to be broken down through education and outreach.

Research has shown that achieving the $20 \%$ wind energy by 2030 vision is technically feasible, and with more than 25 years of wind energy R\&D experience, the Wind Energy Program is well-positioned to help industry make it happen.

\section{Utility-Scale Wind Turbine Successes}

The design of GE Wind Energy's 1.5-MW wind turbine is based on Wind Program work conducted with GE and its predecessors (Zond and Enron). Beginning in the early 1990s, the program worked with these companies to test components such as blades, generators, and control systems on the various generations of machines that led to GE's 1.5-MW workhorse. In November 2008, GE hit a milestone when it shipped its 10,000th 1.5-MW turbine.

Another project that has seen commercial success is the 2.5-MW wind turbine manufactured by Clipper Windpower, Carpinteria, California. Clipper produced a prototype of its 2.5-MW Liberty wind turbine in 2005 after only 3 years of cooperative research and development work with the DOE Wind Program. In 2007, Clipper received an Outstanding Research and Development Partnership Award from DOE for the design and development of the Liberty turbine. The award recognized the turbine's "unparalleled levels of efficiency and reliability and reduced cost of energy."

Clipper anticipates installing more than 300 wind turbines by the end of 2009, and plans to expand production further in 2010. The company currently has sufficient plant capacity and equipment, a trained workforce, and processes in place to assemble more than 500 Liberty turbines each year.

\section{Small Wind Turbine Successes}

Northern Power Systems and the Wind Program at NREL received R\&D 100 award for the development of the NorthWind 100/20 wind turbine. The North Wind 100/20 wind turbine is a state-of-the-art wind turbine designed for operation in remote, cold-climate conditions.

Southwest Windpower received a 2006 Best of What's New Award from Popular Science for its Skystream 1.8-kW wind generator, developed in partnership with the DOE Wind Program. The Skystream was also recognized by Time Magazine as one of the "Best Inventions in 2006."

Windward Engineering worked with the Wind Energy Program to produce a 4.25-kW machined called the Endurance. The company began commercial production of the machine in 2008. 


\section{Wind and Hydropower Technologies Program Contacts}

Megan McCluer, Program Manager

Jim Ahlgrimm, Technology Acceptance Team Lead

Stan Calvert, Technology Application Team Lead

Dennis Lin, Technology Viability Team Lead

Alejandro Moreno, Water Power Team Lead

Office of Wind and Hydropower Technologies

Energy Efficiency and Renewable Energy

1000 Independence Ave., SW

Washington, D.C. 20585
Geunter Conzelmann

Argonne National Laboratory

9700 S. Cass Avenue

Argonne, IL 60439

Vasilis Fthenakis

Brookhaven National Laboratory

Energy Sciences \& Technology Department

MS 130

Upton, NY 11973-5000

Gary Seifert

Idaho National Laboratory

2525 N Fremont

Idaho Falls, ID 83415

Ryan Wiser

Lawrence Berkeley National Laboratory

1 Cyclotron Road MS 90-4126K

Berkeley, CA. 94720

Nalu Kaahaaina

Lawrence Livermore National Laboratory

P.0. Box 808

Livermore, CA 94551-9234

Karl Joneitz

Los Alamos National Laboratory

30 Bikini Atoll Rd

Los Alamos, NM 87545
Brian Smith, Manager

National Renewable Energy Laboratory

National Wind Technology Center

1617 Cole Blvd., MS 3811

Golden, C0. 80401

Brennan Smith

Oak Ridge National Laboratory

P.O. Box 2008,

MS 6036

1 Bethel Valley Rd.

Oak Ridge, TN 37831

Suresh Baskaran

Pacific Northwest National Laboratory

P.O. Box 999

Richland, WA 99352

Jose R. Zayas, Manager

Sandia National Laboratories

Wind Energy Technology Department

P. 0 . Box 5800

Albuquerque, NM 87185-1124

\section{Wind Energy Web Sites}

U.S. DEPARTMENT OF ENERGY WIND AND

HYDROPOWER TECHNOLOGIES PROGRAM:

http://www1.eere.energy.gov/windandhydro/

AMERICAN WIND ENERGY ASSOCIATION:

http://www.awea.org/

NATIONAL RENEWABLE ENERGY LABORATORY

NATIONAL WIND TECHNOLOGY CENTER:

http://www.nrel.gov/wind/

SANDIA NATIONAL LABORATORIES:

http://www.sandia.gov/wind/

NATIONAL WIND COORDINATING COLLABORATIVE:

http://www.nationalwind.org/

UTILITY WIND INTEGRATION GROUP:

http://www.uwig.org

WIND POWERING AMERICA:

http://www.windpoweringamerica.gov

DATABASE OF STATE INCENTIVES FOR RENEWABLES

\& EFFICIENCY: http://www.dsireusa.org/

ARGONNE NATIONAL LABORATORY, UPPER GREAT PLAINS

WIND ENERGY PROGRAMMTIC EIS:

http://plainswindeis.anl.gov/index.cfm

LAWRENCE LIVERMORE NATIONAL LABORATORY, USING

COMPUTATIONAL TOOLS TO ENHANCE WIND POWER:

https://www-eng.IInl.gov/

PACIFIC NORTHWEST NATIONAL LABORATORY, GLOBAL

ENERGY TECHNOLOGY STRATEGY PROGRAM:

http://www.pnl.gov/gtsp/research/renewables.stm

For more information contact:

EERE Information Center

1-877-EERE-Inf (1-877-337-3463)

www.eere.energy.gov

\section{Produced for the} recommendation, or favoring by the United States government or any agency thereof. The views and opinions of authors expressed herein do not necessarily state or reflect those of the United States government or any agency thereof.

Available electronically at www.osti.gov/bridge

Available for a processing fee to U.S. Department of Energy and its contractors, in paper, from:

U.S. Department of Energy, Office of Scientific and Technical Information, P.0. Box 62,

Oak Ridge, TN 37831-0062

phone: 865.576.8401 • fax: 865.576.5728 • email: reports@adonis.osti.gov

Available for sale to the public, in paper, from:

U.S. Department of Commerce, National Technical Information Service, 5285 Port Royal Road,

Springfield, VA 22161

phone: $800.553 .6847 \bullet$ fax: 703.605 .6900

email: orders@ntis.fedworld.gov•online ordering: www.ntis.gov/ordering.htm

PHOTO CREDITS: Cover photos: Iberdrola Renewables, NREL/PIX 15192; Southwest Windpower, NREL/ PIX 14936; Iberdrola Renewables, NREL/PIX 16110; Gamesa, NREL/PIX 16001; L. Fingersh, NREL/PIX 13956; Enron Wind, NREL/PIX 10654; Page 3: Clipper Windpower, NREL/PIX 14932; Scott Bryant Photography, NREL PIX 16150. Page 4: Sandia National Laboratories, NREL/PIX 11071; Sandia National Laboratories, NREL/ PIX 13957; L. Fingersh, NREL/PIX 15005; L. Fingersh, NREL/PIX 15004. Page 6: Sandia National Laboratories; Page 7: A. Reseburg, NREL/PIX 16039. Page 9: S. Hughes, NREL/PIX 14708; Page 12: Northern Power Systems, NREL/PIX 15387. Page 13: A. Bowen, NREL/PIX 15705. Page 14: W. Gretz, NREL/PIX 0001. Page 17: Edison Mission Group, NREL/PIX 16135; Tim Nauman, NREL/PIX 16101; NRG Energy, NREL/PIX 16095; Vision Energy, NREL/PIX 16108; First Wind, NREL/PIX 16060; First Wind, NREL/PIX 16101. Page 18: Invenergy LLC, NREL/PIX 16042; R. Gough, NREL/PIX 15954. Page 21: Jenny Hager Photography, NREL/PIX 14913.

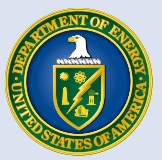

U.S. DEPARTMENT OF energy

\section{Energy Efficiency \& Renewable Energy}

1000 Independence Avenue, SW, Washington, DC 20585

Prepared by the National Renewable Energy Laboratory (NREL) NREL is a national laboratory of the U.S. Department of Energy Office of Energy Efficiency and Renewable Energy Operated by the Alliance for Sustainable Energy, LLC

DOE/G0-102009-2803

April 2009 